\title{
PopFor: A new model for estimating poplar yields
}

Running title: A new model for estimating poplar yields

Dagmar N. Henner ${ }^{1}$, Astley Hastings ${ }^{1}$, Mark Pogson ${ }^{2}$, Niall P. McNamara ${ }^{3}$, Christian A. Davies $^{4} \&$ Pete Smith $^{1}$

${ }^{1}$ Institute of Biological and Environmental Sciences, University of Aberdeen, 23 St Machar Drive, Aberdeen, AB24 3UU, UK, ${ }^{2}$ Quintessa Ltd., First Floor, West Wing, Videcom House, Newtown Road, Henley-on-Thames, Oxfordshire RG9 1HG, UK, ${ }^{3}$ Centre for Ecology \& Hydrology, Lancaster Environment Centre, Library Avenue, Bailrigg, Lancaster, LA1 4AP, UK, ${ }^{4}$ Shell International Exploration and Production Inc., Shell Technology Centre Houston, 3333 Highway 6 South, Houston, Texas 77082, USA.

Corresponding author: Dagmar N. Henner, tel. +44 (0)1224 272702, fax +44 (0) 12242 72703, email: dagmar.henner@abdn.ac.uk

\section{Highlights}

- New poplar model for predicting yield estimates on a local or larger scale

- PopFor needs only soil and weather data, no diameter or stem measurements

- PopFor accurately modelled yield for $2^{\text {nd }}$ rotation poplar coppice and intensively managed $1^{\text {st }}$ rotation poplar coppice and the parameters are widely applicable

- PopFor is a suitable tool for defining the most suitable areas for poplar bioenergy 


\begin{abstract}
Lignocellulosic bioenergy crops are a potential option for climate mitigation and for meeting the targets of the Paris Agreement in Europe. The PopFor process-based model has been developed based on the earlier MiscanFor model and parameterised for poplar using data from a literature review in combination with experimental data on high performing clones Max 1, 3, 4 for extensively and intensively managed sites in Germany. PopFor needs comparatively few input data to provide accurate estimates of biomass yield. The parameters found allowed a good match to measured values. The best fit for bud emergence is 81 degree days (base 5), with leaf emergence at 463degree days (base 5) and the temperature at which photosynthesis slows is $28{ }^{\circ} \mathrm{C}$. Maximum radiation use efficiency was set to $2.9 \mathrm{gMJ}^{-1}$. The air temperature threshold that kills crop was set at $-37^{\circ} \mathrm{C}$ with the number of days below this threshold that kills the crop set at 90 days. 30 days below wiltpoint was set as a threshold that kills the crop from drought. It was found that plant available water was the key explanatory variable in predicting yield and access to groundwater explained $97 \%$ of the yield variation between the sites. The results show that the model estimates the yield of poplar after the establishment phase with a mean difference of $0.27 \mathrm{DM} \mathrm{tha}^{-1} \mathrm{y}^{-1}\left(\mathrm{r}^{2} 0.99, \mathrm{n} 29, \mathrm{~F}=4.18, \mathrm{p}<0.05\right.$ with RMSE $=19.68 \%$ ). PopFor was shown to be an effective model for predicting yields under different soil conditions.
\end{abstract}

Keywords: PopFor, poplar, bioenergy crop, process-based model, yield, parameterisation 


\section{Introduction}

This paper describes the first parameterisation of the new PopFor model, developed from the earlier MiscanFor model [1-3] and SalixFor model [4], as a tool for estimating potential poplar bioenergy yields. Most published poplar models require sample measurements of stem diameters, height and numbers which are used to develop a yield estimate equation. PopFor, in contrast, does not require any poplar measurements as it is a model calculating photosynthesis processes.

Poplar is a suitable lignocellulosic bioenergy crop for large parts of Europe and already widely planted [5-11]. Due to its physiological traits, it is fast growing and Populus clones are widely adaptable to different site conditions, which makes poplar an ideal candidate for short rotation coppice or forestry [12-14]. Another factor in favour of poplar in Europe is, that in contrast to other bioenergy crops, e.g. Switchgrass, there are no concerns about it being an invasive species because poplar is native all over Europe [15-18].

Bioenergy has been proposed as a feedstock for delivering energy security and for closing the gap between current fossil fuels and other renewable energy sources, e.g. soil, wind, wave, and as a potential factor for mitigating climate change, through substitution of fossil fuels, thereby reducing net greenhouse gas (GHG) emissions from energy production [7,19-23]. Recent analyses suggest that up to $20 \%$ of global energy demand could be met by biomass without negative impacts on food supply [24,25].

In order to improve the effectiveness of bioenergy, the development of second-generation bioenergy technologies based on the conversion of lignocellulosic plant materials from fastgrowing tree and grass species to various energy feedstocks has received a lot of attention recently [26]. These energy crops, such as poplar, willow and Miscanthus are not as dependent on favourable climatic and soil conditions as food crops and require fewer inputs 
of agrochemicals $[7,21,27,28]$. Lignocellulosic bioenergy crops like poplar can therefore be planted on more marginal land, unsuitable for growing food crops, which reduces their direct competition with food production [29]. Because most of the harvested aboveground biomass can be converted into energy (not just the grain or oil), per-area energy yields are innately greater [7,27,30-34].

Although bioenergy is not without potential trade-offs [34-36], its potential for low carbon energy production has led to considerable attention over recent years [21,34,35]. A potential way to improve the carbon balance of bioenergy production, and also carbon sequestration by poplar, is the use of bioenergy coupled with carbon capture and storage [35,37-41]. Scenarios that assume that $\mathrm{CO}_{2}$ emissions will continue to rise as they currently still do and do not peak before 2030, demonstrate the potential for a large bioenergy sector, coupled with carbon capture and storage [42] in order to limit global warming to $2{ }^{\circ} \mathrm{C}$, with sufficient likelihood of meeting the Paris Climate Agreement target $[40,43]$.

Knowledge about potential future poplar yields in Europe will allow for optimum use of these bioenergy crops. Currently, many medium and long term field experiments with different genotypes produce yield and phenotype data that can be used as a basis for model parameterisation [26,44-49]. Process-based models are useful tools for assessing potential yields, plant traits and evaluating environmental interactions, especially in lignocellulosic bioenergy crops where long growth cycles over multiple rotations make data collection expensive and time consuming $[48,50]$. When properly parameterised, models like PopFor can provide insights to support policy for renewable energy development and can be used to predict yields under different climatic and soil conditions. Poplar physiological traits, e.g. water use, leaf area, biomass development and partitioning and radiation use efficiency (RUE), change greatly with genotype and environment $[6,8,11-14,51-53]$. The process of 
finding the optimum set of parameters for PopFor, especially in the very dry area of Brandenburg, Germany, is described in this article.

\section{Methods}

\subsection{Description of the PopFor model}

The PopFor yield model is based on the MiscanFor process-based model described by [1-3]. This model has been parameterised for poplar using values for plant growth by $[54,55]$ and is called PopFor.

The plant growth module is driven by air temperature and incident photosynthetically active radiation by using a given RUE coefficient (Fig. 1). Modelling plant growth in PopFor requires a daily time series of maximum temperature, minimum temperature, precipitation, potential evapotranspiration (PET) and photosynthetically active radiation (PAR). Data for global radiation are widely available and PAR can be estimated as 50\% Global Radiation [56]. Measurements of PET are rarely available for specific sites. Therefore, PopFor either takes available PET data or estimates this variable based on available meteorological data, using the empirical Thornthwaite equation [57] which calculates PET from mean temperature where insufficient information is available to use the Penman Monteith methodology [58]. As the original Thornthwaite PET equation was developed for moist climates, the FAO correction (Penmanfactor) [59] is used to correct for drier climates and years with low rainfall. This uses the variations in the annual rainfall to produce a value that closely resembles the Penmen-Monteith calculation [58]. Details of the equations are given in [1]. 


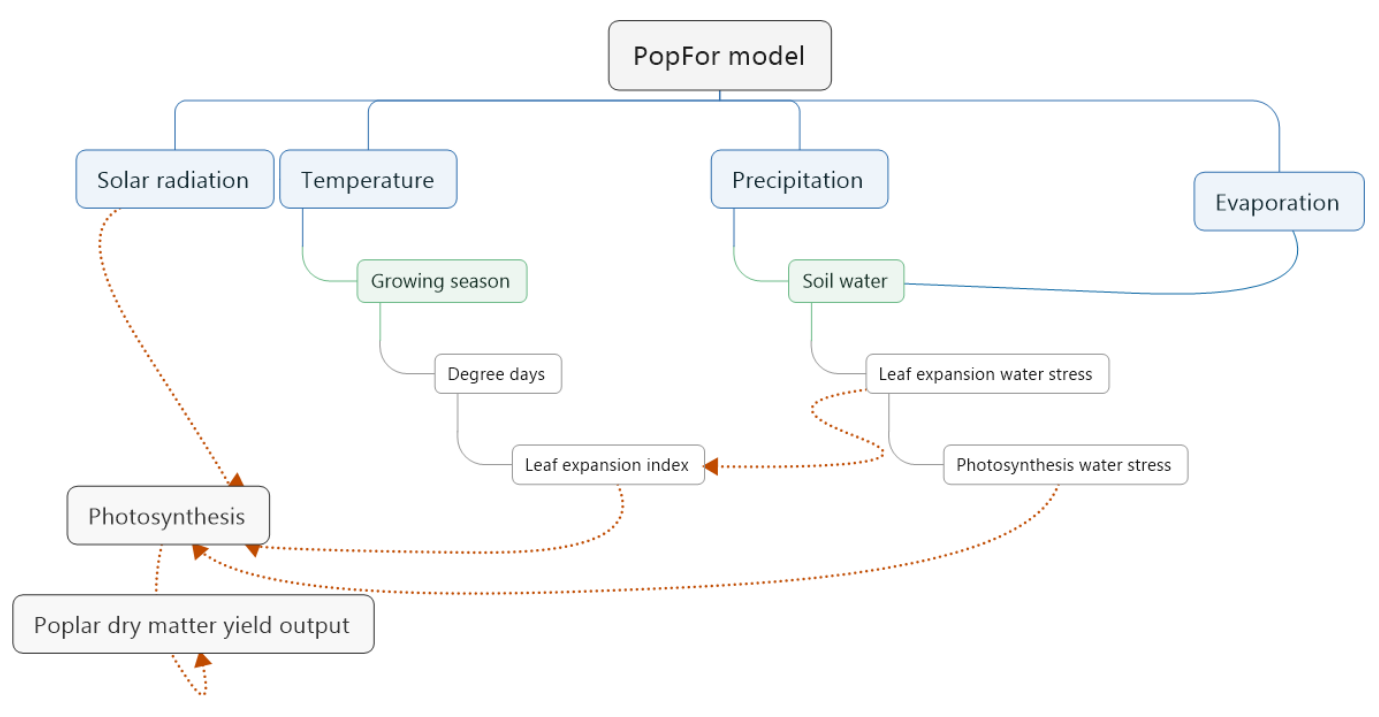

Fig.1: Description of the processes in the PopFor model.

Actual evapotranspiration, AET, in PopFor is calculated as a proportion of PET in a three-step process: evaporation of rainfall intercepted by leaf and stalk, leaf transpiration related to leaf area index (LAI) and limited by the capillary pressure of the remaining soil water, and evaporation from the soil by diffusion through air-filled soil space. The difference between actual evapotranspiration (AET) and precipitation is used to determine the daily soil water change and the soil water deficit (SWD). The SWD is used to calculate capillary pressure threshold (CPT) of the remaining soil water. $\mathrm{CPT}$ is then used in a linear downregulation factor for photosynthesis. RUE is a function of the temperature of leaf formation, the temperature at the time of photosynthesis and the soil moisture deficit. Water use efficiency (WUE) is calculated by dividing the AET during crop growth by the dry matter. Details of the processes, including an example, are given in [1].

PopFor provides daily incremental leaf area index and accumulated biomass in DM t ha $\mathrm{y}^{-1}$ on a given site. PopFor is designed to model the yields for an established crop (i.e. after first rotation rather than the establishment period before the first harvest) but has been shown to 
model the results of well-established and intensively managed poplar coppice during any plant life stage.

\subsection{Determining the poplar parameters from literature}

PopFor parameters include parameters defining the beginning of plant growth, plant survival and photosynthesis rates: DDshoot which is the cumulative degree day factor above 5 degrees Celsius for bud emergence, DDleaf which is the cumulative degree day factor above 5 degrees Celsius for leaf emergence, DDleafdrop which is the cumulative degree day factor for earliest leaf senescence, DDdieback which is the cumulative degree day factor for plant growth cessation were based on a SWAT model analysis done on some of the sites used for this parameterisation by [55]. Before doing the SWAT model analysis, Hartwich et al. tested the applicability of generic poplar parameters in the SWAT model and measured DD values for poplar growth over the year. DD values from [54] were used as they are derived from the

same area of Germany (Brandenburg) and the same poplar clones (Max 1, 3, 4; Table 1). The physiological timeclock in PopFor (Physiostat) is driven by cumulative degree days above 1 ${ }^{\circ} \mathrm{C}\left(\mathrm{DD}_{1}\right)$. The phases driven by it are: dormancy, budding, leaf emergence, leaf growth and leaf senescence when LAI is reduced. These Degree day parameters, measured by [55] are used as defaults in the PopFor model. Budburst occurred at 81 degree days base 5 degC (DD5), equivalent to $262 \mathrm{DD}_{1}$ or after journal day 71 (JD) whichever is sooner. Leaf senescence starts when day length is $12 \mathrm{hrs}, \mathrm{JD}=235$ or first frost, whichever is sooner. The conditions that trigger each poplar growth phase are shown in the literature to vary with genotype and as such are variables in in the PopFor model $[60,61,54,62,8,6,11,63,14]$. Cumulative degree days above $5{ }^{\circ} \mathrm{C}$ is used to estimate the total growing season, which was reported to be 2031 degree days [54,55]. These parameters were tested for their ability to predict the yields of the genotypes used in the German experimental sites. These values also 
fit well with research done by [14] who found that bud flush occurred between day of year (DOY) 70 and DOY 108 and bud set between DOY 240 and DOY 270.

For LAImax which is the LAI pivot point for senescence rate, we found that the best fitting parameter was $4 \mathrm{~L}$. This was based on [14,54] who measured radiation use efficiency of poplar on sites in Scotland and Belgium and tested the impact on LAI and biomass development. Extcoef which is the light interception extinction coefficient, was set at $0.5 \mathrm{k}$ based on [64] who tested and partly re-parameterised the 3PG model for poplar short rotation plantations in Sasketchewan, Canada. The value for extinction coefficient remained unchanged at the default value of the 3PG model [65]. RUE, which is the maximum RUE, was set at $2.9 \mathrm{gMJ}^{-1}$ based on the above mentioned research of [54]. There is wide research on RUE in poplar and published values vary greatly with climate, time of year, clone and management of the plot from around $0.8 \mathrm{gMJ}$ to $2.9 \mathrm{gMJ}^{-1}[8,14,54,62,64,66,67]$. To address this problem, PopFor calculates a variable RUE as follows. Maximum possible RUE for above ground biomass when there is no water, temperature or nutrient constraints present depends on genotype. The default value is $2.9 \mathrm{~g} \mathrm{MJ}^{-1}$, determined by [54], because new high performing clones are developed for higher RUE. This value is reduced by three factors: temperature, nutrient and water stress. Details of the processes, including an example are given in [1]. For GrowthreshT, which is the temperature threshold for start of leaf growth, we used $5{ }^{\circ} \mathrm{C}$ which is widely recommended for broadleaf trees in temperate areas [68-71]. Optimum temperature for poplar has been reported around $20^{\circ} \mathrm{C}[14,54,64,69]$ while overheat reaction on poplar leaves does take higher temperatures [72]. We therefore set the overheat parameter, which is the overheat threshold for RUE when RUE begins to decline with temperature, at $28^{\circ} \mathrm{C}$ because clones like the ones used in this research have been chosen for their suitability to higher temperatures. LeafTexp, which is the exponential factor for leaf development temperature, PhotoT, the temperature threshold for photosynthesis and 
PhotoTexp, the !temperature exponent for photosynthesis were based on research by $[70,71]$

(Table 1).

The parameters for LAIfslow, which is the PAW at which leaf expansion slows, RUEfslow, the plant available water (PAW) at which photosynthesis slows, and AEPEfslow, the PAW at which evapotranspiration slows, were based on the research by [70,71] (Table 1). Harvestrat, the parameter for the ratio of peak harvest to spring harvest was set at $70 \%$ and is based on data from [60] (Table 1).

As poplar is sensitive to drought stress, especially spring drought, conditions that result in plant death are calculated in PopFor. Plant death means that growth stops in that year and the crop would need to be replanted the following year. In the model, the number of days the soil water content is below the wilting point is Dkilldry. The Killdry values indicated in the literature varied between $30-50$ [7,66,66,73-78] and especially the research of $[54,55,79,80]$. Drought stress in poplar is a complex function of genotype, phenology, climate and groundwater. Research shows that drought stress of 30 days had already significant impact on the biomass partitioning, growth, leaf survival and embolism of poplar, with variation between genotypes and days [54,76-79]. Further, $70 \%$ of 226 forest species from 81 sites worldwide operate with narrow ( $<1$ megapascal) hydraulic safety margins against detrimental levels of drought stress [79]. We set the drought death value at 45 days, because of observations from the field published widely $[66,70,73,74,78,80]$. PopFor also uses a value for frost kill (winter kill). Frost kill can happen in Northern Europe [81-84]. The value was set as a mean daily air temperature of $-20{ }^{\circ} \mathrm{C}$ (Tkillcold) for a period of $>90$ days (Dkillcold).

Table 1: List of parameters in the PopFor model including the references for the research which forms the basis of this first parameterisation.

\begin{tabular}{|c|c|c|}
\hline Parameters & Parameter description & References \\
\hline 1 & $\begin{array}{cc}\text { BaseT } & \text { base temperature for DD was } \\
\text { "Growthresh" }\end{array}$ & \\
\hline 81 & DDshoot DD for shoot emergence & Hartwich et al. 2016 \\
\hline 463 & DD for leaf emergence & Hartwich et al. 2016 \\
\hline
\end{tabular}




\begin{tabular}{|c|c|c|}
\hline 500 & $\begin{array}{c}\text { DDwiltthresh earliest DD for drought impact } \\
\text { after rhizome reserves }\end{array}$ & Broeckx et al. 2014 \\
\hline 1767 & DDleafdrop DD for earliest leaf senescence & Hartwich et al. 2016 \\
\hline 2031 & DDdieback growth cessation & Hartwich et al. 2016 \\
\hline 3200 & $\begin{array}{c}\text { DDend of cycle not used as } 365 \text { days is } \\
\text { end }\end{array}$ & \\
\hline 0 & $\begin{array}{l}\text { photoswitch photosensitivity switch day use } 81 \\
\text { for day } 0 \text { for not }\end{array}$ & \\
\hline 5 & $\begin{array}{c}\text { DDTb DDbase for growing season - NOT } \\
\text { USED }\end{array}$ & \\
\hline 2200 & $\begin{array}{cc}\text { Growtime } & \begin{array}{c}\text { DD of growing season DDbase - } \\
\text { NOT used }\end{array}\end{array}$ & \\
\hline 5.5 & $\begin{array}{c}\text { LAIthresh Zero crossing of DD v LAI - NOT } \\
\text { used }\end{array}$ & \\
\hline 0.5 & $\begin{array}{c}\text { LAIfslow pu of PAW at which leaf expansion } \\
\text { slows }\end{array}$ & Schreiber et al. 2013, Schildbach 2014 \\
\hline 0.75 & $\begin{array}{c}\text { RUEfslow pu of PAW at which } \\
\text { photosynthesis slows }\end{array}$ & Schreiber et al. 2013, Schildbach 2014 \\
\hline 0.25 & $\begin{array}{l}\text { AEPEfslow pu of PAW at which evapo- } \\
\text { transpiration slows }\end{array}$ & Schreiber et al. 2013, Schildbach 2014 \\
\hline 1500 & wiltpoint wiltpoint capillary pressure $\mathrm{kPa}$ & \\
\hline 607 & wiltstart point on onset of drought stress kpa & \\
\hline 10 & fieldcap field capacity capillary pressure $\mathrm{kPa}$ & \\
\hline 3 & $\begin{array}{cl}\text { AELAImax } & \begin{array}{l}\text { maximum LAI for AE/PE } \\
\text { calculation }\end{array} \\
\end{array}$ & \\
\hline 4 & LAImax LAI pivot point for senescence rate & Cannell et al. 1988, Verlinden et al. 2013 \\
\hline 0.006 & $\begin{array}{cc}\text { DDfactor } & \begin{array}{c}\text { slope of relationship between LAi } \\
\text { and DD }\end{array} \\
\end{array}$ & \\
\hline 0.1 & $\begin{array}{c}\text { LAIdec } \begin{array}{c}\text { Decline rate of LAI at senescence } \\
\mathrm{LAI} / \mathrm{d}\end{array} \\
\end{array}$ & \\
\hline 2.9 & RUE maximum radiation use efficiency & Cannell et al. 1988 \\
\hline 0.5 & Extcoef extinction coefficient & Amichev et al. 2010 \\
\hline 5 & $\begin{array}{l}\text { GrowthreshT temperature threshold for start of } \\
\text { leaf growth }\end{array}$ & Schreiber et al. 2013, Schildbach 2014 \\
\hline 4.75 & $\begin{array}{cc}\text { LeafTexp } & \begin{array}{c}\text { Exponent coef for leaf development } \\
\text { temperature }\end{array}\end{array}$ & Schreiber et al. 2013, Schildbach 2014 \\
\hline 6 & $\begin{array}{ll}\text { PhotoT } & \begin{array}{l}\text { temperature threshold for } \\
\text { photosynthesis }\end{array} \\
\end{array}$ & Schreiber et al. 2013, Schildbach 2014 \\
\hline 5 & $\begin{array}{c}\text { PhotoTexp temperature exponent for } \\
\text { photosynthesis }\end{array}$ & Schreiber et al. 2013, Schildbach 2014 \\
\hline 28 & $\begin{array}{c}\text { overheat overheat threshold for RUE, when } \\
\text { RUE declines with temp }\end{array}$ & \\
\hline 0.03 & $\begin{array}{c}\text { Oheatfac } \begin{array}{c}\text { Decline rate of RUE with overheat } \\
\text { temperature }\end{array} \\
\end{array}$ & \\
\hline 0.2 & $\begin{array}{c}\text { Harvestrat ratio of peak harvest to spring } \\
\text { harvest }\end{array}$ & Cannell et al. 1988 \\
\hline 90 & $\begin{array}{c}\text { Dkillcold days below killcold threshold that } \\
\text { kills crop }\end{array}$ & Sakai 1965, Schreiber et al. 2013 \\
\hline 30 & Dkilldry days below wiltpoint that kills crop & Schildbach 2014 \\
\hline-20 & $\begin{array}{c}\text { Tkillcold air temperature threshhold that kills } \\
\text { crop }\end{array}$ & Sakai 1965, Schreiber et al. 2013 \\
\hline 4 & $\begin{array}{l}\text { soilTKill Mean annual } \mathrm{T} \text { when ground } \\
\text { temperature }>0 \text { with snow cover }\end{array}$ & \\
\hline
\end{tabular}

\subsection{Genotype, phenotype and soil data from 37 test sites used to parameterise the}

\section{model}


We used a comprehensive dataset from 37 BIODEM project sites from Brandenburg, Germany [85], growing first and second rotation poplar, to understand the factors affecting poplar growth. Management details including date of planting and harvesting, genotype and information on irrigation, weed control, management during establishment phase and management type (intensive or extensive) are shown in Table A1.

The sites were established as trial sites between 0.5 and 0.7 ha on former agricultural land or land that had previously been taken out of use. Soil types have been determined based on Adhoc AG Boden 2005 [86], which is the German standard for soil mapping, and groundwater depth was measured using a Nordmeyer cable-acoustic-rod. Soil cores were taken from the sites and analysed to provide a complete suite of physical and chemical characteristics including $\mathrm{pH}$ - value $\left(\mathrm{H}_{2} \mathrm{O}, \mathrm{KCl}\right)$, humus content in the top soil $>30 \mathrm{~cm}, \%$ clay, $\%$ silt, $\%$ sand, orgC, $\mathrm{CACO}_{3}$. These data were used to calculate the field capacity (mm), wilt point (mm) and soil organic carbon $\left(\mathrm{Mg} \mathrm{ha}^{-1}\right)$ using the Campbell method $[3,87]$.

Prior to planting, the plots were tilled using a furrow plough. In the establishment years of 2007 and 2008, an extreme spring drought impacted the experiments, so the plants were irrigated in the weeks after planting. Weed control was performed manually and with small scale gardening machines (e.g. rotovator and mulcher) as the plots were fenced. Not all plots were treated equally, neither in intensity nor frequency, with irrigation and herbicides. Herbicides (glyphosate products Flexidor and Fusilade Max) were used at the Drieschnitz, Groß Radden (Flexidor) and Zeischa (Flexidor) sites only. The differences in treatment are based on the former land use and the plant communities found. The comparison of extensive and intensive sites categorised based on the above-explained different treatment can be found in the site description (Table A1).

The Populus stems were planted in double rows with 14,815 trees per ha which is higher than the usual commercial planting density of up to 10,000 plants per ha. Further details of the 
planting and measurement process can be found in Schlepphorst et al., (2017). All trial plots were established as randomised plot trials with 5 replicates, each plot between 0.5 and 0.7 ha. Plants were planted in double rows with $150 \mathrm{~cm}$ between each double row and $60 \mathrm{~cm}$ between individual plants in the double rows (coppice spacing). Hardwood cuttings of $20 \mathrm{~cm}$ were planted at all sites except for Kummerow 1. In this very poor soil plot, the short cuttings planted in 2006 and 2007 died from spring drought. Therefore, replanting in 2008 was done using $80 \mathrm{~cm}$ hardwood cuttings which had been drilled $60 \mathrm{~cm}$ into the soil.

Potential yield was based on a growth regression which is explained in detail in [85]. After each 3-year rotation, the diameter of all poplar stems more than $8 \mathrm{~mm}$ thick was recorded at 1 m height above ground. The maximum height was also measured. Only trees on plots with a survival rate of $75 \%$ or more in the central and border areas were sampled. Yield potential measurements were based on trees in the centre of each plots only, so that edge effects were minimised. Based on measurements of these samples, an allometric biomass function, which is a reliable way to determine the dry matter yield per ha, was developed $[85,88,89]$ (Table 2).

Table 2: Biomass function used to determine the Max 1, Max 2 and Max 3 Yields based on Schlepphorst et al. 2017

\begin{tabular}{|c|c|c|c|c|}
\hline Species & Genotype & Function & $\mathbf{N}(\mathbf{x})$ & $\mathbf{r}^{2}$ \\
\hline Populus spec. & Max 1 & $\mathrm{y}=95.516 \mathrm{x}^{1.1752}$ & 55 & 0.9927 \\
\hline Populus spec. & Max 3 & $\mathrm{y}=97.115 \mathrm{x}^{1.1838}$ & 48 & 0.9865 \\
\hline Populus spec. & Max 4 & $\mathrm{y}=96.624 \mathrm{x}^{1.1662}$ & 60 & 0.9856 \\
\hline \\
$\mathrm{x}=$ shoot diameter $\left(\mathrm{cm}^{2}\right)$ in $1 \mathrm{~m}$ height; $\mathrm{y}=$ shoot weight \\
\hline
\end{tabular}

The data used in this study for testing the functioning of PopFor model for yield modelling relate only to Max 1, Max 3 and Max 4 clones (section Tacamahaca, Populus maximowiczii x nigra), with the vast majority of 29 being Max 1 (Table A1). One plot at Gross Radden had been planted with Max 3, another one with Max 4 and on the three Stendell 2 plots Max 4 was tested.

\subsection{Soil water data}


PAW and groundwater access are important factors for poplar growth. Soil water saturation data available from the Kummerow and Stendell poplar sites were used in a prior research using the SWAT model analysis of groundwater. The data included a time series for two years of soil moisture at 10, 20, 30, 40, 60, and $100 \mathrm{~cm}$ depth. This data was used to validate the PopFor model predictions of soil moisture level and plant water use [55].

The method from [87] for estimating the water holding capacity for mineral soil compositions was used to determine the wilting point and field capacity at each of the sites from the soil analysis of each plot. Campbell's soil water retention function is comparatively simple, only requiring a curve-shape parameter (the pore-size distribution parameter) and the saturated water content at the air-entry soil water potential as inputs. The results are used as PAW in the PopFor model. Groundwater access is not currently available in the model when used spatially but can be modelled at site level by switching off water stress.

\subsection{Climate data used to drive the model}

PopFor requires daily meteorological data for cloud cover (\%), precipitation (mm), temperature range $\left({ }^{\circ} \mathrm{C}\right)$ and mean temperature $\left({ }^{\circ} \mathrm{C}\right)$ which was accessed from the Deutscher Wetterdienst online archive (CDW Klimadaten Deutschland ftp://ftpcdc.dwd.de/pub/CDC/help/). This data came from the station in Berlin-Tegel (Latitude 52.564, Longitude 13.309) and was used for all sites because of the lack of some measurements from other weather stations closer to the sites. The climate between the sites should be similar based on the fact that this is a very flat and homogeneous area, but intrayear variability is high.

\subsection{Sensitivity study of parameters}

The model was run with these default parameters based on [54,55] for all sites. To investigate if these parameters could be optimized to improve the match of the model to the German 
experimental data, each parameter (DDshoot, DDleaf, DDleafdrop, DDdieback, LAImax, Extcoef, RUE, GrowthreshT, overheat) was varied in steps of $10 \%$ to limits above and below the default values shown in Table 3, whilst keeping the other parameters constant.

Table 3: Comparison of parameters tested in the sensitivity analysis with original parameters in the PopFor model.

\begin{tabular}{|c|c|c|c|c|c|c|c|c|c|}
\hline Parameter & DDshoot & DDleaf & DDleafdrop & DDdieback & RUE & LAImax & Extcoef & GrowthreshT & overheat \\
\hline Hartwich et al & 81 & 436 & 1767 & 2031 & & & & & \\
\hline Cannell et al & & & & & 2.9 & 4 & 1.49 & & \\
\hline lowest & 70 & 150 & 1500 & 2000 & 1 & 3 & 1 & 4 & 21 \\
\hline increments & 10 & 10 & 10 & 10 & 0.5 & 0.5 & 0.5 & 1 & 1 \\
\hline highest & 300 & 500 & 2000 & 3200 & 5 & 6 & 3 & 6 & 28 \\
\hline
\end{tabular}

We assumed that the rainfall was the same at each of the sites as they are close by and in a very flat area so that differences in the soil PAW must be responsible for most of the variations in yield due to water availability. This was tested in the PopFor model by matching measured yields by varying PAW to achieve a match. This was compared against the site soil descriptions.

The bulk density varied between $1.2 \mathrm{~g} \mathrm{~cm}^{3}$ and $1.8 \mathrm{~g} \mathrm{~cm}^{3}$ over all sites. Lindhorst has the highest clay content (30 to $34.5 \%$ depending on the plot) and the lowest organic carbon (orgC) content with $0.28 \%$ up to $0.93 \%$. On these sites the groundwater table was between 0.5 and $1.65 \mathrm{~m}$ below ground and therefore within rooting depth for the mature poplar plants. This soil type would be ideal for poplar which needs almost constant water access and can survive in flooded areas without problems $[10,55,77,80,90]$. This is reflected by the measured yields available from this BIODEM sites. We therefore switched off the water stress and ran the model with almost constant PAW which enabled the PopFor model predictions to match the higher yields. The three best performing plots at the Lindhorst site could not be explained by PAW only. We therefore tested if changes in biomass partitioning had an impact on potential modelled yields. While poplar plants are young, 25\% biomass are partitioned into leaves, $42 \%$ biomass are partitioned into stems and $22 \%$ biomass are partitioned into roots 
[54]. It seems logical that the poplar crops at this suitable site would reach the groundwater and based on that start to grow more above ground biomass which would increase the potential yield. We tested this assumption by increasing maximum RUE to $4.5 \mathrm{gMJ}^{-1}$ to demonstrate that this can allow PopFor to reach the very high yields around $20 \mathrm{DM} \mathrm{tha} \mathrm{t}^{-1}$ at Lindhorst site.

As stated before, PopFor was parameterised to model the yields of established and managed poplar bioenergy crops. Based on the initial runs on all sites, without detailed tests of PAW, we also tested how well PopFor can simulate measured yield results at the sites where economically viable yields (>10 DM tha $\mathrm{DH}^{-1} \mathrm{y}^{-1}$ ) have been found.

It was noted that in this very dry area, soils have a direct impact on plant growth. Even within one plot or between neighbouring plots, yields can vary greatly. This is caused by several aspects, e.g. groundwater level, topography, neighbouring lakes or channels, neighbouring vegetation just to name some. This variation was investigated by examining google earth images of the sites. Images of the adjacent Gross Radden and Cahnsdorf plots exhibit characteristics indicating the area is very dry with dry sandy patches visible all over the plots and around them. At some sites, especially Kummerow 1, even the second rotation yield was almost nil. We tested this effect by reducing the PAW in the PopFor model until PAW matched the measured and modelled yields. We also looked for specific differences in site conditions between individual plots at the low yielding sites to verify if one single or a combination of several factors can be responsible for the bad establishment of the poplar crops.

\subsection{Independent evaluation of PopFor}

PopFor was independently evaluated against measured poplar yield results from several sites across Europe (Brandenburg, Germany [55,85], Belgium [8,11], Italy [5,12,91], the UK 
[3,21,92,93], Denmark [11,14,94], Czech Republic [95] and Austria [personal communication], Table A2). The overall yield for all the sample sites in Europe in Table A2 is 9.07 $\mathrm{DM} \mathrm{tha} \mathrm{t}^{-1} \mathrm{y}^{-1}$ which is a yield amount that can be found on good but not optimal sites in Europe but also in other temperate regions, e.g. the USA. The sites were chosen so that each climate region in Europe is represented. Some sites are very dry while others receive large amounts of precipitation regularly. The chosen sites are all published apart from the Austrian sites near Vienna where data has been assessed by personal communication. All sites report annual yields apart from Paris et al. [91] where biannual yields were reported and divided by two for comparison. Soil and climate data were derived from the publications, if suitably presented, or else derived from open source climate and soil data banks. The PopFor model was run with the parameters found during this research. PAW was not changed apart from the very low performing sites $\left(<6 \mathrm{DM} \mathrm{tha}^{-1} \mathrm{y}^{-1}\right)$.

\subsection{Statistical tests for assessing model performance during calibration and evaluation}

The results were tested for statistical significance of means by ANOVA and some plots have been done in the statistical package Minitab 18. The MODEVAL package [96,97] was used for the majority of the statistical tests (i.e. t-test, lack of fit, correlation) because it was developed for the comparison of modelled with measured results. The process was repeated until the best fitting parameters were established.

\section{Results}

\subsection{Model performance for sites used in calibration}

PopFor model predictions at the Brandenburg sites with the highest yields $>10 \mathrm{DM} \mathrm{tha} \mathrm{t}^{-1} \mathrm{y}^{-1}$ matched the observed yields (Fig. 2). Modelling unlimited plant available water was required to match the highest yields demonstrating that poplar trees need large quantities of water to 
reach these yields. However, PAW variation alone could not explain the two highest yields which were only possible with higher RUE values. A linear regression gives a unity relationship with an $\mathrm{r}^{2}=1(\mathrm{n} 31, \mathrm{~F}=4.18, \mathrm{p}<0.05$ with $\mathrm{RMSE}=1 \%$, two-tailed students $\mathrm{t}$ test is 2.06 with a mean difference of $0.2 \mathrm{DM} \mathrm{tha}^{-1} \mathrm{y}^{-1}$ ) for the poplar results. Statistical analysis confirms that there is a significant association, no significant bias and no significant error between measured and modelled yield results. Mean result measured over the high yield sites is 13.61 DM t ha' $\mathrm{y}^{-1}$ compared with 13.63 $\mathrm{DM} \mathrm{tha}^{-1} \mathrm{y}^{-1}$ with the optimum PAW.

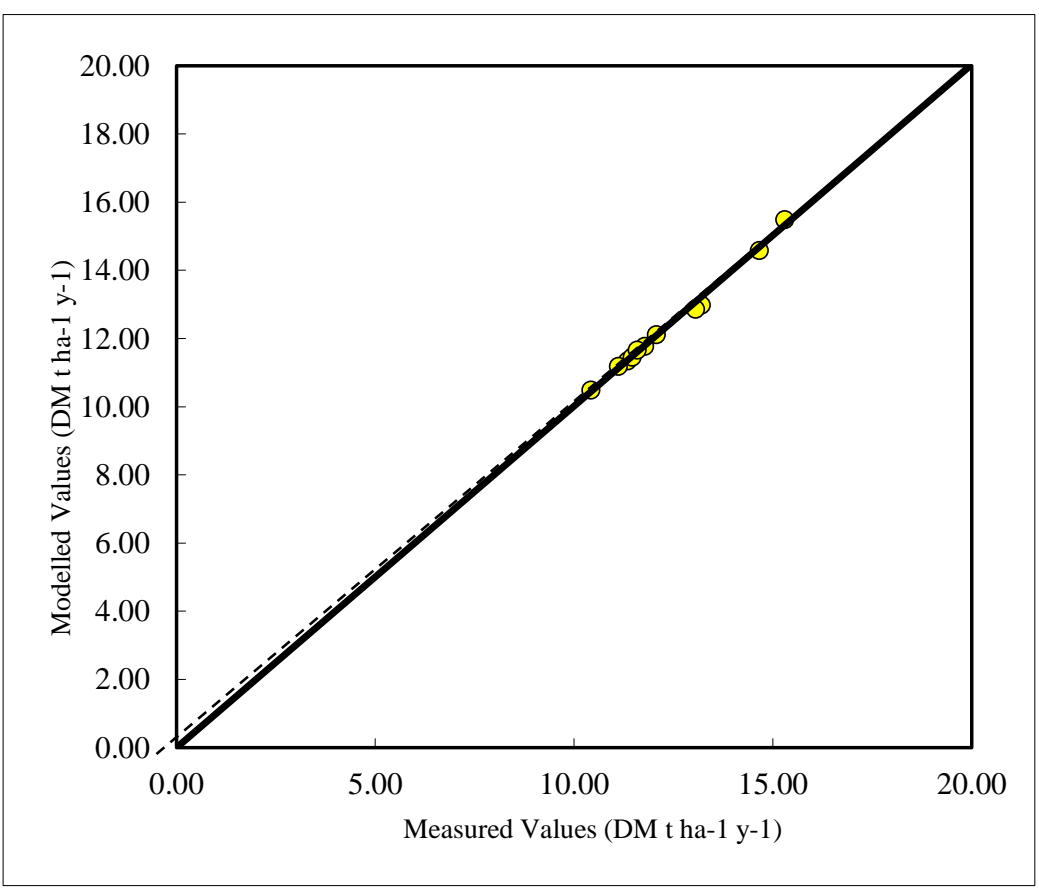

Fig. 2: Comparison of the sites with the highest yields of >10 DM $t h a^{-1} y^{-1}$. The modelled and experimental yields are closely correlated.

Using the highest yielding experimental plots and eliminating the plant available water variation, the sensitivity study confirmed that the default values for DDshoot is 81 days, with DDleaf set at 436 days. DDleafdrop for earliest leaf senescence was set at 1767 days and for the dieback date for plant senescence (DDdieback) a value of 2031 days were found to be best. $R U E$ was confirmed to be best at $4.5 \mathrm{gMJ}$ for the well-established crops at the Lindhorst site which have a larger potential for optimum radiation use caused by their superior growth. We found that this change in RUE could describe the measured yields above $20 \mathrm{DM} \mathrm{tha} \mathrm{t}^{-1} \mathrm{y}^{-1}$ 
with amounts of PAW that are realistic with groundwater access (Fig. 3). However, for regular modelling with less developed poplars or as an overview when looking for potential poplar yields in a larger spatial area, the default value of $2.9 \mathrm{gMJ}$ was confirmed to create the most reliable results.

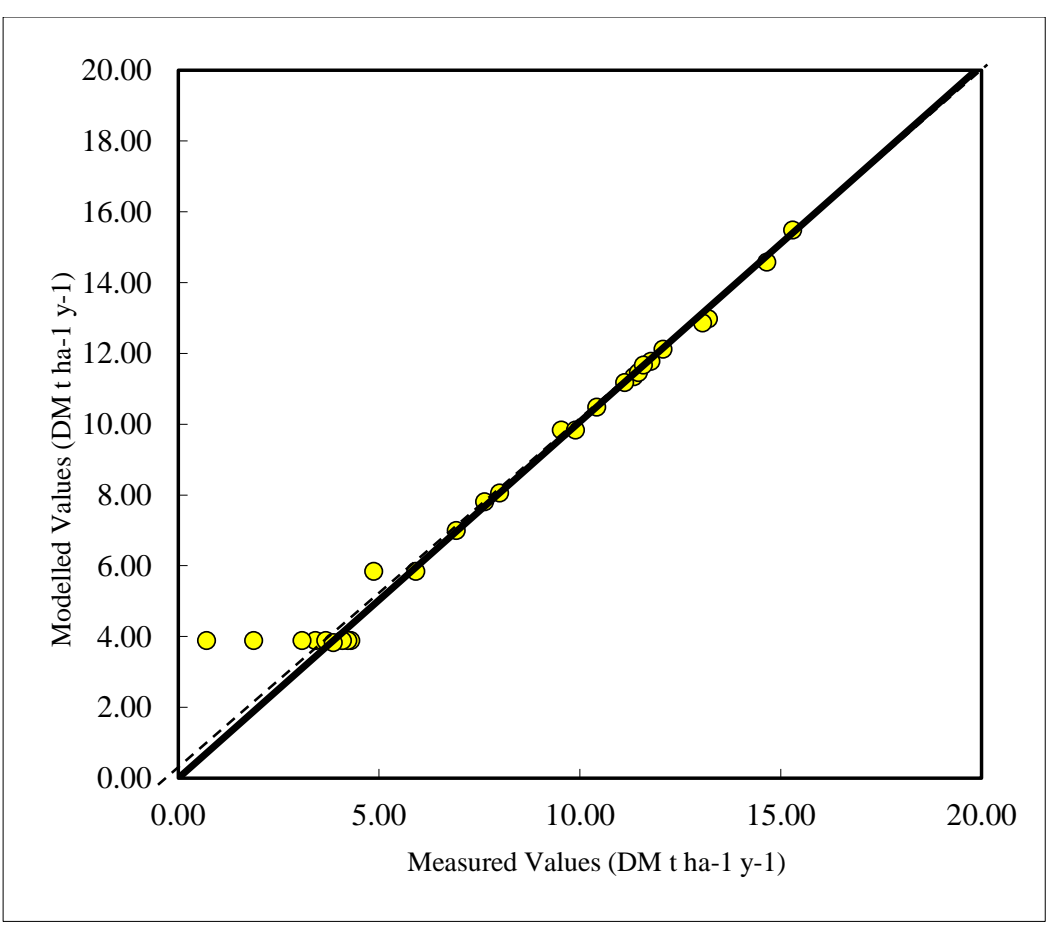

Fig. 3: Plot of the measured against modelled PopFor results for all sites during second harvest with optimum plant available water, plotted against a 1:1 line.

When testing how well PopFor can follow the measured yields of established sites with yields of more than $10 \mathrm{DM} \mathrm{tha}^{-1} \mathrm{y}^{-1}$, but excluding the above tested Lindhorst sites, we found that PopFor could simulate the yields well with no changes needed (Table 4). The mean modelled results over all 10 sites where suitable data on the second harvest was available, is just 0.54 $\mathrm{DM} t \mathrm{ha}^{-1} \mathrm{y}^{-1}$ lower than the mean measured results. A linear regression gives a unity relationship with an $\mathrm{r}^{2} 0.97(\mathrm{n} 10, \mathrm{~F}=5.12, \mathrm{p}<0.05$ with $\mathrm{RMSE}=9.81 \%$, two-tailed students t-test is 2.36 with a mean difference of $0.47 \mathrm{DM} \mathrm{tha}^{-1} \mathrm{y}^{-1}$ ) for the poplar results. Statistical analysis confirms that there is a significant association, no significant bias and no significant error between measured and modelled yield results. Mean result measured over all sites is 
12.06 DM t ha $\mathrm{D}^{-1} \mathrm{y}^{-1}$ compared with 11.52 $\mathrm{DM} \mathrm{tha}^{-1} \mathrm{y}^{-1}$ with the optimum parameter combination.

Table 4: Comparison of measured and modelled PopFor yields at the sites where economically feasible yields above 10 DM $t$ $h a^{-1} y^{-1}$ were found. PopFor can predict these yields well without any changes in PAW and without groundwater being incorporated in the model.

\begin{tabular}{|c|c|c|c|c|}
\hline Plot & Year planted & Harvest & $\begin{array}{c}\text { 2. Harvest } \\
\text { Measured } \\
\text { Yield [DM t ha- } \\
\left.{ }^{1} \mathrm{y}^{-1}\right]\end{array}$ & $\begin{array}{l}\text { PopFor Yield } \\
{\left[\mathrm{DM} \mathrm{tha}{ }^{-1} \mathrm{y}^{-1}\right]}\end{array}$ \\
\hline Cahnsdorf 1 & 2007 & 2013 & 13.19 & 11.96 \\
\hline Drieschnitz & 2008 & 2014 & 12.07 & 11.67 \\
\hline Groß Radden 2 & 2008 & 2014 & 13.05 & 12.08 \\
\hline Groß Radden 2 & 2008 & 2014 & 11.33 & 12.19 \\
\hline Kummerow 2 & 2007 & 2013 & 11.11 & 11.21 \\
\hline Kummerow 2 & 2007 & 2013 & 10.42 & 10.76 \\
\hline Kummerow 3 & 2008 & 2014 & 11.45 & 11.88 \\
\hline Stendell 2 & 2008 & 2014 & 11.77 & 11.13 \\
\hline Stendell 2 & 2008 & 2014 & 14.65 & 11.94 \\
\hline \multirow[t]{2}{*}{ Zeischa } & 2007 & 2013 & 11.58 & 10.34 \\
\hline & & mean & 12.06 & 11.52 \\
\hline
\end{tabular}

As a next step in the sensitivity analysis, PopFor was run to predict yield on all Brandenburg sites. The results are shown in Table 5 with the corresponding value of PAW that was used to obtain a match to the measured yield. For all sites with $>10 \mathrm{DM} \mathrm{tha}^{-1} \mathrm{y}^{-1}$ yield, the modelled yields are compared to the observed yields of all plots in Figure 4. The PAW needed to reach these results varies greatly, between 3,000 $\mathrm{mm}$ and $5 \mathrm{~mm}$ water (Table 5).

Table 5: Results of parameterisation with a comparison of measured and modelled yield results combined with plant available water.

\begin{tabular}{|c|c|c|c|c|c|c|c|c|c|}
\hline Plot & $\begin{array}{c}\text { Year } \\
\text { planted }\end{array}$ & Harvest & $\begin{array}{l}\text { 1. Harvest } \\
\text { Measured } \\
\text { Yield [DM } \\
\mathrm{t} \mathrm{ha}^{-1} \mathrm{y}^{-1} \text { ] }\end{array}$ & $\begin{array}{l}\text { PopFor } \\
\text { Yield } \\
\text { [DM t } \\
\text { ha }^{-1} \mathrm{y}^{-1} \text { ] }\end{array}$ & $\begin{array}{l}\text { PAW } \\
\mathrm{mm}\end{array}$ & Harvest & $\begin{array}{l}\text { 2. Harvest } \\
\text { Measured } \\
\text { Yield [DM } \\
\mathrm{t} \mathrm{ha}^{-1} \mathrm{y}^{-1} \text { ] }\end{array}$ & $\begin{array}{c}\text { PopFor } \\
\text { Yield } \\
\text { [DM t } \\
\text { ha }^{-1} \mathrm{y}^{-1} \text { ] }\end{array}$ & $\begin{array}{l}\text { PAW } \\
\mathrm{mm}\end{array}$ \\
\hline Blumberg SV & 2010 & 2013 & 7.34 & 7.44 & 65 & & & & \\
\hline Blumberg SV & 2010 & 2013 & 5.83 & 5.90 & 30 & & & & \\
\hline Cahnsdorf 1 & 2007 & 2010 & 2.34 & 2.26 & 25 & 2013 & 8.00 & 8.05 & 80 \\
\hline Cahnsdorf 1 & & & & & & 2013 & 13.19 & 12.98 & 300 \\
\hline Drieschnitz & 2008 & 2011 & 1.78 & 1.37 & 5 & 2014 & 9.53 & 9.84 & 75 \\
\hline Drieschnitz & 2008 & 2011 & 1.20 & 1.37 & 5 & 2014 & 12.07 & 12.11 & 160 \\
\hline Drieschnitz & 2008 & 2011 & 1.40 & 1.37 & 5 & 2014 & 3.41 & 3.88 & 10 \\
\hline Groß Radden 2 & 2008 & 2011 & 2.19 & 1.37 & 5 & 2014 & 4.29 & 3.88 & 10 \\
\hline
\end{tabular}




\begin{tabular}{|c|c|c|c|c|c|c|c|c|c|}
\hline Groß Radden 2 & 2008 & 2011 & 5.28 & 5.66 & 10 & 2014 & 7.62 & 7.81 & 30 \\
\hline Groß Radden 2 & 2008 & 2011 & 5.57 & 5.66 & 10 & 2014 & 13.05 & 12.86 & 300 \\
\hline Groß Radden 2 & 2008 & 2011 & 5.85 & 5.66 & 10 & 2014 & 11.33 & 11.34 & 120 \\
\hline Kummerow 1 & 2008 & 2011 & 1.35 & 1.37 & 5 & 2014 & 3.07 & 3.88 & 10 \\
\hline Kummerow 1 & 2008 & 2011 & 1.23 & 1.37 & 5 & 2014 & 1.87 & 3.88 & 10 \\
\hline Kummerow 1 & 2008 & 2011 & 3.15 & 1.37 & 5 & 2014 & 0.70 & 3.88 & 10 \\
\hline Kummerow 1 & 2008 & 2011 & 0.54 & 1.37 & 5 & 2014 & 3.67 & 3.88 & 10 \\
\hline Kummerow 2 & 2007 & 2010 & 5.80 & 5.95 & 100 & 2013 & 11.11 & 11.18 & 165 \\
\hline Kummerow 2 & 2007 & 2010 & 4.20 & 4.05 & 65 & 2013 & 10.42 & 10.48 & 145 \\
\hline Kummerow 3 & 2008 & 2011 & 0.20 & 1.37 & 5 & 2014 & 4.86 & 5.84 & 15 \\
\hline Kummerow 3 & 2008 & 2011 & 0.15 & 1.37 & 5 & 2014 & 4.22 & 3.88 & 10 \\
\hline Kummerow 3 & 2008 & 2011 & 0.98 & 1.37 & 5 & 2014 & 11.45 & 11.46 & 125 \\
\hline Kummerow 3 & 2008 & 2011 & 0.18 & 1.37 & 5 & 2014 & 4.08 & 3.88 & 10 \\
\hline Kummerow 3 & 2008 & 2011 & 0.37 & 1.37 & 5 & 2014 & 9.89 & 9.84 & 75 \\
\hline Lindhorst & 2006 & 2009 & 0.28 & 1.84 & 5 & 2012 & 15.29 & 15.48 & 130 \\
\hline Lindhorst & 2006 & 2009 & 1.26 & 1.84 & 5 & 2012 & 20.80 & 20.92 & 2000 \\
\hline Lindhorst & 2006 & 2009 & 2.76 & 1.84 & 5 & 2012 & 20.26 & 20.41 & 1800 \\
\hline Schönholz 1 & 2011 & 2014 & 7.20 & 7.45 & 25 & & & & \\
\hline Schönholz 1 & 2011 & 2014 & 6.77 & 6.80 & 20 & & & & \\
\hline Schönholz 2 & 2011 & 2014 & 8.25 & 8.32 & 40 & & & & \\
\hline Schönholz 2 & 2011 & 2014 & 9.03 & 9.03 & 55 & & & & \\
\hline Schönholz 2 & 2011 & 2014 & 8.12 & 8.07 & 35 & & & & \\
\hline Stendell 2 & 2008 & & & & & 2014 & 5.91 & 5.84 & 15 \\
\hline Stendell 2 & 2008 & & & & & 2014 & 11.77 & 11.77 & 140 \\
\hline Stendell 2 & 2008 & & & & & 2014 & 14.65 & 14.58 & 3000 \\
\hline Zeischa & 2007 & 2010 & 2.42 & 2.26 & 25 & 2013 & 6.91 & 7.00 & 55 \\
\hline Zeischa & 2007 & 2010 & 5.28 & 5.11 & 80 & 2013 & 11.58 & 11.66 & 180 \\
\hline \multirow[t]{2}{*}{ Zeischa } & 2007 & 2010 & 1.43 & 2.26 & 25 & 2013 & 3.86 & 3.83 & 20 \\
\hline & & mean & 3.43 & 3.60 & & & 8.93 & 9.18 & \\
\hline
\end{tabular}




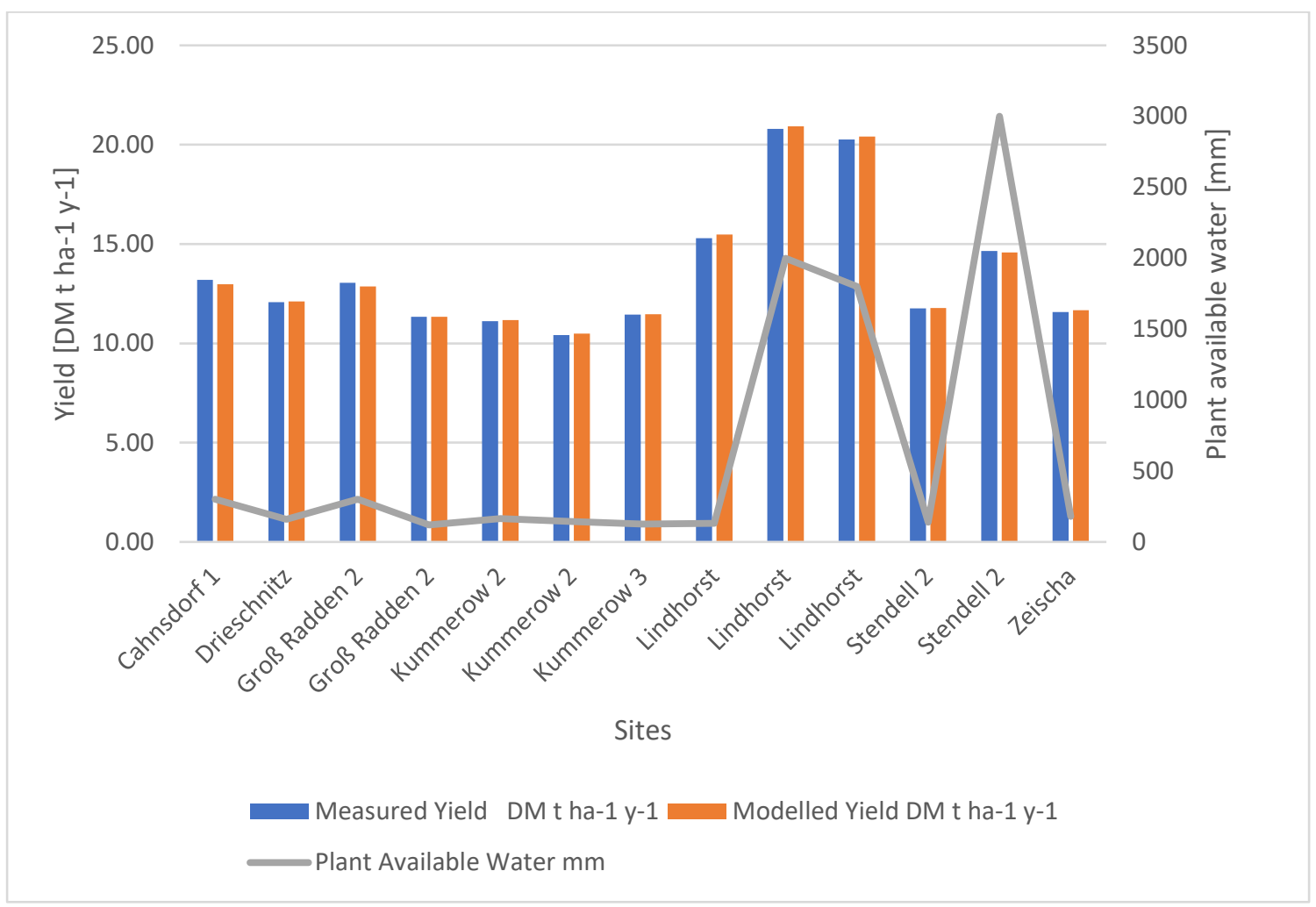

Fig. 4: Comparison of measured and modelled yield results for all sites with yields above $10 \mathrm{DM} t \mathrm{ha}^{-1} \mathrm{y}^{-1}$.

The mean modelled results over all 29 sites where data on the second harvest was available, is just $0.26 \mathrm{DM} \mathrm{tha}^{-1} \mathrm{y}^{-1}$ higher than the mean measured results. A linear regression gives a unity relationship with an $\mathrm{r}^{2} 0.99(\mathrm{n} 29, \mathrm{~F}=4.18$, $\mathrm{p}<0.05$ with $\mathrm{RMSE}=16.68 \%$, two-tailed students t-test is 2.06 with a mean difference of $-0.27 \mathrm{DM} \mathrm{tha}^{-1} \mathrm{y}^{-1}$ ) for the poplar results. Statistical analysis confirms that there is a significant association, no significant bias and no significant error between measured and modelled yield results. The mean result measured over all sites is 8.93 $\mathrm{DM} \mathrm{tha}^{-1} \mathrm{y}^{-1}$ compared with 9.18 $\mathrm{DM} \mathrm{tha}^{-1} \mathrm{y}^{-1}$ with the optimum parameter combination. Analysis of means in Anova (Minitab 18) shows that the means of measured and modelled results are almost equal $\left(r^{2}=1, n 29\right)$.

The mean modelled results over all 31 sites where data on the first harvest was available, is 0.17 DM t ha ${ }^{-1} \mathrm{y}^{-1}$ higher than the mean measured results. A linear regression gives a unity 
relationship with an $\mathrm{r}^{2} 0.97(\mathrm{n} 31, \mathrm{~F}=4.18, \mathrm{p}<0.05$ with $\mathrm{RMSE}=8.37 \%$, two-tailed students $\mathrm{t}$-test is 2.05 with a mean difference of $0.17 \mathrm{DM} \mathrm{tha}^{-1} \mathrm{y}^{-1}$ ) for the poplar results. Statistical analysis confirms that there is a significant association, no significant bias and no significant error between measured and modelled yield results. Mean yield measured over all sites is 3.43 DM t ha $\mathrm{y}^{-1} \mathrm{y}^{-1}$ compared with a simulated yield of 3.60 $\mathrm{DM} \mathrm{tha}^{-1} \mathrm{y}^{-1}$ with the optimum parameter combination. Analysis of means in Anova (Minitab 18) shows that the means of measured and modelled results are almost equal $\left(r^{2} 1, n 31\right)$. Analysis of the PAW confirmed that $5 \mathrm{~mm}$ PAW allowed PopFor to follow sites with extremely low yields around or below 2 DM t ha ${ }^{-1} \mathrm{y}^{-1}$ (Table 5).

The comparison of measured and modelled yield results at the Kummerow 1, 2 and 3 sites demonstrates how important soil and groundwater access are for poplar development in drier climates (Fig. 5). At Kummerow 1, poplar did not establish well and even during $2^{\text {nd }}$ harvest, yields were well below $4 \mathrm{DM} \mathrm{tha} \mathrm{D}^{-1} \mathrm{y}^{-1}$. At Kummerow 2, which received a slightly more intensive manual treatment during establishment, $1^{\text {st }}$ rotation yields were low $\left(<6 \mathrm{DM} \mathrm{tha}^{-1} \mathrm{y}^{-}\right.$ ${ }^{1}$ ) but $2^{\text {nd }}$ rotation yields did reach economically acceptable yields over $10 \mathrm{DM} \mathrm{tha} \mathrm{ha}^{-1}$. At Kummerow 3 plots, poplar did not produce any notable yields during $1^{\text {st }}$ rotation $\left(<2 \mathrm{DM} \mathrm{t} \mathrm{ha}^{-}\right.$ ${ }^{1} \mathrm{y}^{-1}$ ) but $2^{\text {nd }}$ rotation yields are much higher than found at Kummerow 1 with yields between $4 \mathrm{DM} \mathrm{tha} \mathrm{D}^{-1} \mathrm{y}^{-1}$ and almost $12 \mathrm{DM} \mathrm{tha}^{-1} \mathrm{y}^{-1}$. PAW improved at all sites from $1^{\text {st }}$ harvest $(5 \mathrm{~mm}$ to $100 \mathrm{~mm}$ ) to $2^{\text {nd }}$ harvest ( $10 \mathrm{~mm}$ to $165 \mathrm{~mm}$ ) (Table 5). 


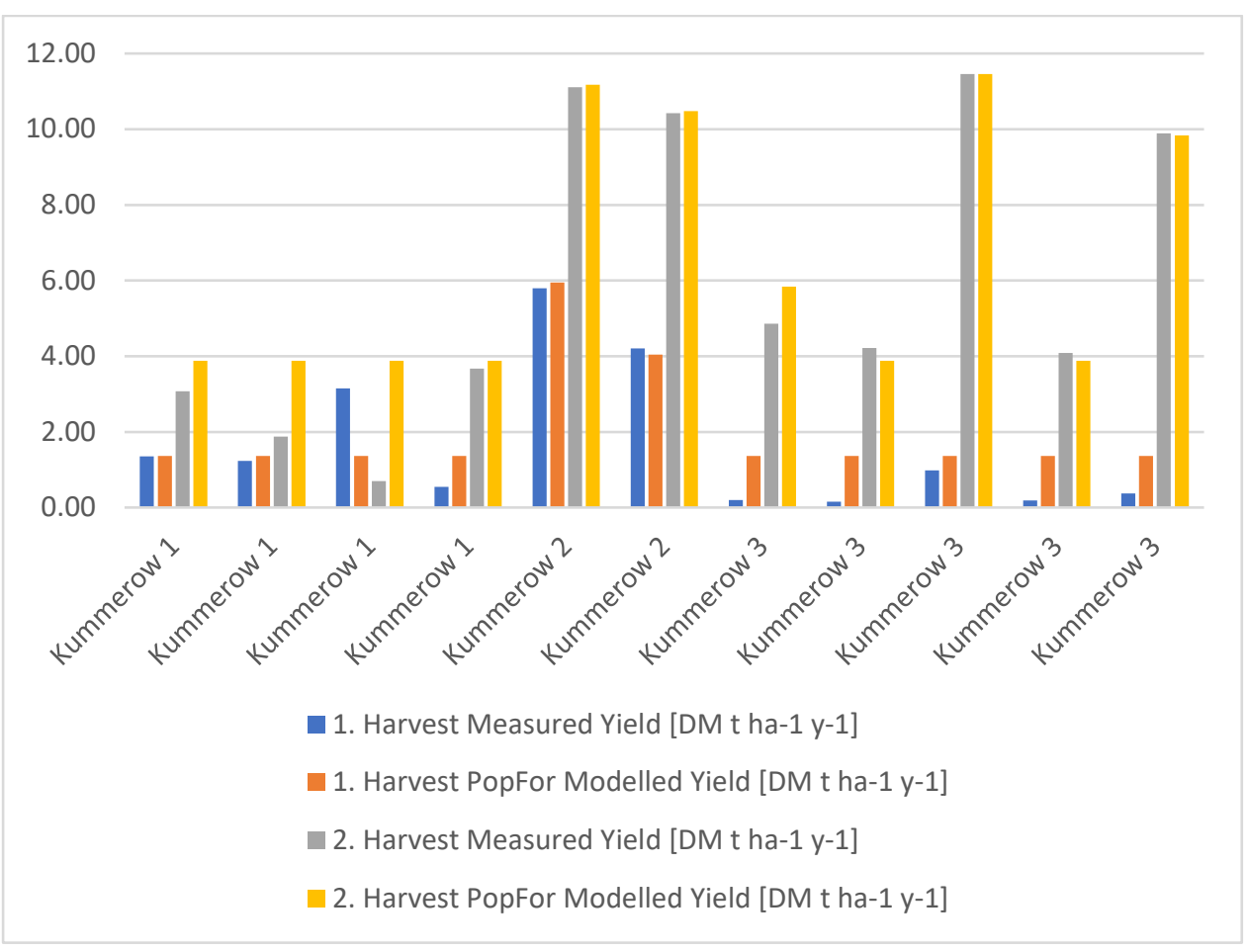

Fig. 5: Kummerow 1, 2 and 3 measured and modelled yields show how much plant development changes with establishment, soil and groundwater access.

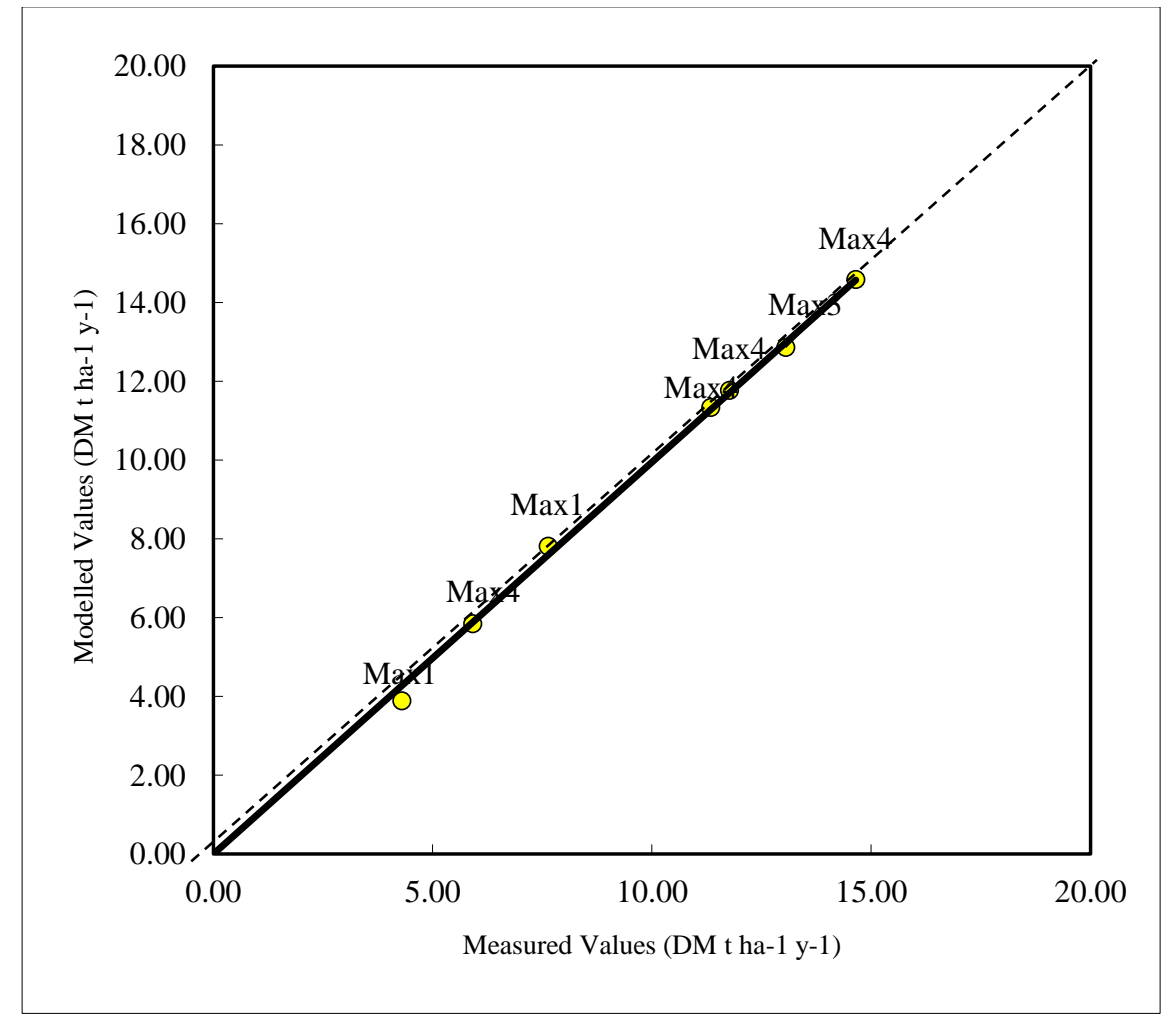

Fig. 6: A comparison of measured and modelled yield results at Gross Radden and Stendell sites. In this comparison are Max 1, Max 3 and Max 4 genotypes included.

Looking at the Gross Radden (extensively managed) and Stendell (intensively managed) plots at $2^{\text {nd }}$ harvest, a linear regression gives a unity relationship with an $\mathrm{r}^{2}=1(\mathrm{n} 7, \mathrm{~F}=4.18, \mathrm{p}<$ 
0.05 with $\mathrm{RMSE}=1.27 \%$, two-tailed students t-test is 2.06 with a mean difference of 0.02 $\mathrm{DM} \mathrm{tha} \mathrm{t}^{-1} \mathrm{y}^{-1}$ ) for the poplar results. This analysis includes two (compared to the overall site yield), of the lower results, with some higher results and all clones in this research (Fig. 6). Max 3 and Max 4 produce the highest yields at these sites. The only Max3 yield comes from Gross Radden. The comparison of measured groundwater level and soil water content at Stendell with the modelled soil water deficit from PopFor shows that the model can follow the soil water content and the reactions to large rain events, but the lack of groundwater in the model is obvious (Fig. 7). The PAW needed to match the inhomogeneous yields at this site varies between $10 \mathrm{~mm}$ and $3000 \mathrm{~mm}$ in year 2012 and 2013.

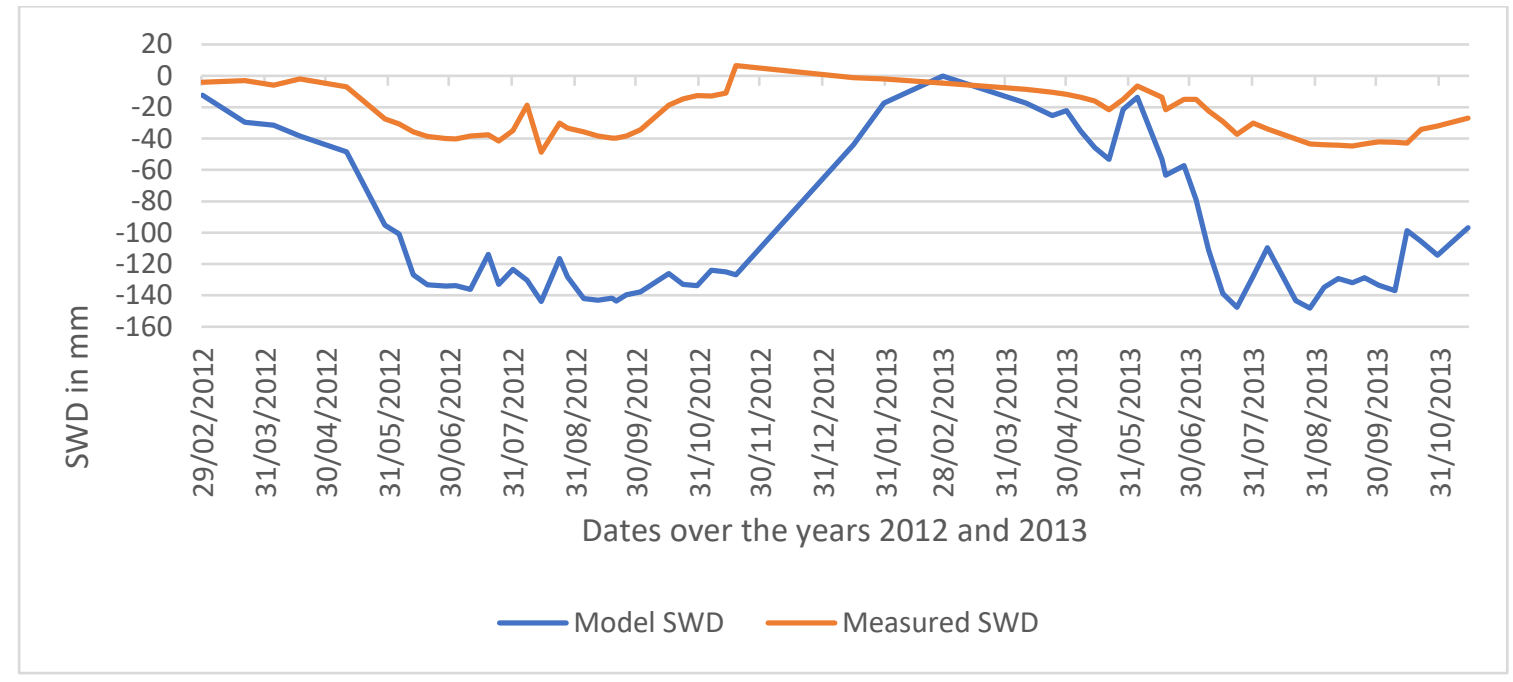

Fig. 7: Measured ground water level in cm and modelled soil water deficit in mm at Stendell site.

At Lindhorst plot, where yields of $20 \mathrm{DM} \mathrm{tha}^{-1} \mathrm{y}^{-1}$ were measured, the soil is very inhomogeneous but includes only 52\% sand, the lowest amount of sand on all BIODEM sites, which shows the importance of soil in addition to groundwater access. At Kummerow 1, the site with the overall lowest yield, where even the $2^{\text {nd }}$ rotation yield is just $0.7 \mathrm{DM} \mathrm{tha}^{-1} \mathrm{y}^{-1}$ to 3.1 $\mathrm{DM} \mathrm{tha}^{-1} \mathrm{y}^{-1}$, the soil includes $92.5 \%$ sand (the highest value over all sites) and has a very low water holding capacity. The area has appropriately been named "sand mountain". This 
complete non-establishment of poplar at this site demonstrates how important groundwater access is for establishing poplar bioenergy plantations.

The detailed analysis of first and second rotation on intensively managed sites demonstrates the impact of management during the establishment phase (Table 6, Fig. 8). The overall mean measured yield of intense management sites of 8.49 $\mathrm{DM} \mathrm{tha}^{-1} \mathrm{y}^{-1}$ is slightly less than the mean yield of all second rotation sites of 8.9 DM tha $\mathrm{DH}^{-1} \mathrm{y}^{-1}$. The Stendell sites show second rotation intensive management results (mean measured yield $10.77 \mathrm{DM} \mathrm{tha}^{-1} \mathrm{y}^{-1}$ ) while the other 7 sites are first rotation intensive management results (mean measured yield 6.17 DM t $\mathrm{ha}^{-1} \mathrm{y}^{-1}$ ) which demonstrates the fast development on well-managed plots even when other factors, e.g. soil, precipitation, are not favourable. A linear regression gives a unity relationship with an $\mathrm{r}^{2}=1(\mathrm{n} 10, \mathrm{~F}=4.18, \mathrm{p}<0.05$ with $\mathrm{RMSE}=0.65 \%$, two-tailed students $\mathrm{t}-$ test is 2.31 with a mean difference of $-0.03 \mathrm{DM} \mathrm{tha}^{-1} \mathrm{y}^{-1}$ ) for the intensive management poplar results. The overall measured yield of $1^{\text {st }}$ rotation extensive management plots is only 2.3 DM tha ${ }^{-1} \mathrm{y}^{-1}$ (Table 5). The comparison of $1^{\text {st }}$ rotation intensive and extensive measured yields shows how much degradation in yields is caused by poor management in the establishment phase (Fig. 9). Testing the PAW with PopFor demonstrates that the plants in the intensive management plots do have more water available, since weeds in extensive plots use the water (Fig. 10). Intensive management can offset the poor soil conditions and allow poplar to establish well (Fig. 9). The comparison of measured percent sand and modelled PAW at each site shows that these are linked. Sites with a large amount of sand do need higher PAW to reach high yields (Fig. 10).

Table 6: Intensive Management $1^{\text {st }}$ and $2^{\text {nd }}$ rotation with the Stendell sites being $2^{\text {nd }}$ harvest and all other sites $1^{\text {st }}$ harvest. Associated PAW shows how much water is available for the poplar plants at each site.

\begin{tabular}{|c|c|c|c|c|c|}
\hline & $\begin{array}{c}\text { Year } \\
\text { planted }\end{array}$ & Harvest & $\begin{array}{c}\text { Measured } \\
\text { Yield [DM t ha } \\
\left.1 \mathrm{y}^{-1}\right]\end{array}$ & $\begin{array}{c}\text { PopFor Yield } \\
{\left[\mathrm{DM} \mathrm{t} \mathrm{ha}{ }^{-1} \mathrm{y}^{-1}\right]}\end{array}$ & $\begin{array}{c}\text { PAW } \\
\mathrm{mm}\end{array}$ \\
\hline Blumberg SV & 2010 & 2013 & 7.34 & 7.44 & 65 \\
\hline Blumberg SV & 2010 & 2013 & 5.83 & 5.90 & 30 \\
\hline
\end{tabular}




\begin{tabular}{|c|c|c|c|c|c|} 
Schönholz 1 & 2011 & 2014 & 7.20 & 7.45 & 25 \\
\hline Schönholz 1 & 2011 & 2014 & 6.77 & 6.80 & 20 \\
\hline Schönholz 2 & 2011 & 2014 & 8.25 & 8.32 & 40 \\
\hline Schönholz 2 & 2011 & 2014 & 9.03 & 9.03 & 55 \\
\hline Schönholz 2 & 2011 & 2014 & 8.12 & 8.07 & 35 \\
\hline Stendell 2 & 2008 & 2014 & 5.91 & 5.84 & 15 \\
\hline Stendell 2 & 2008 & 2014 & 11.77 & 11.77 & 140 \\
\hline Stendell 2 & 2008 & 2014 & 14.65 & 14.58 & 3000 \\
\hline & & mean & 8.49 & 8.52 & \\
\hline
\end{tabular}

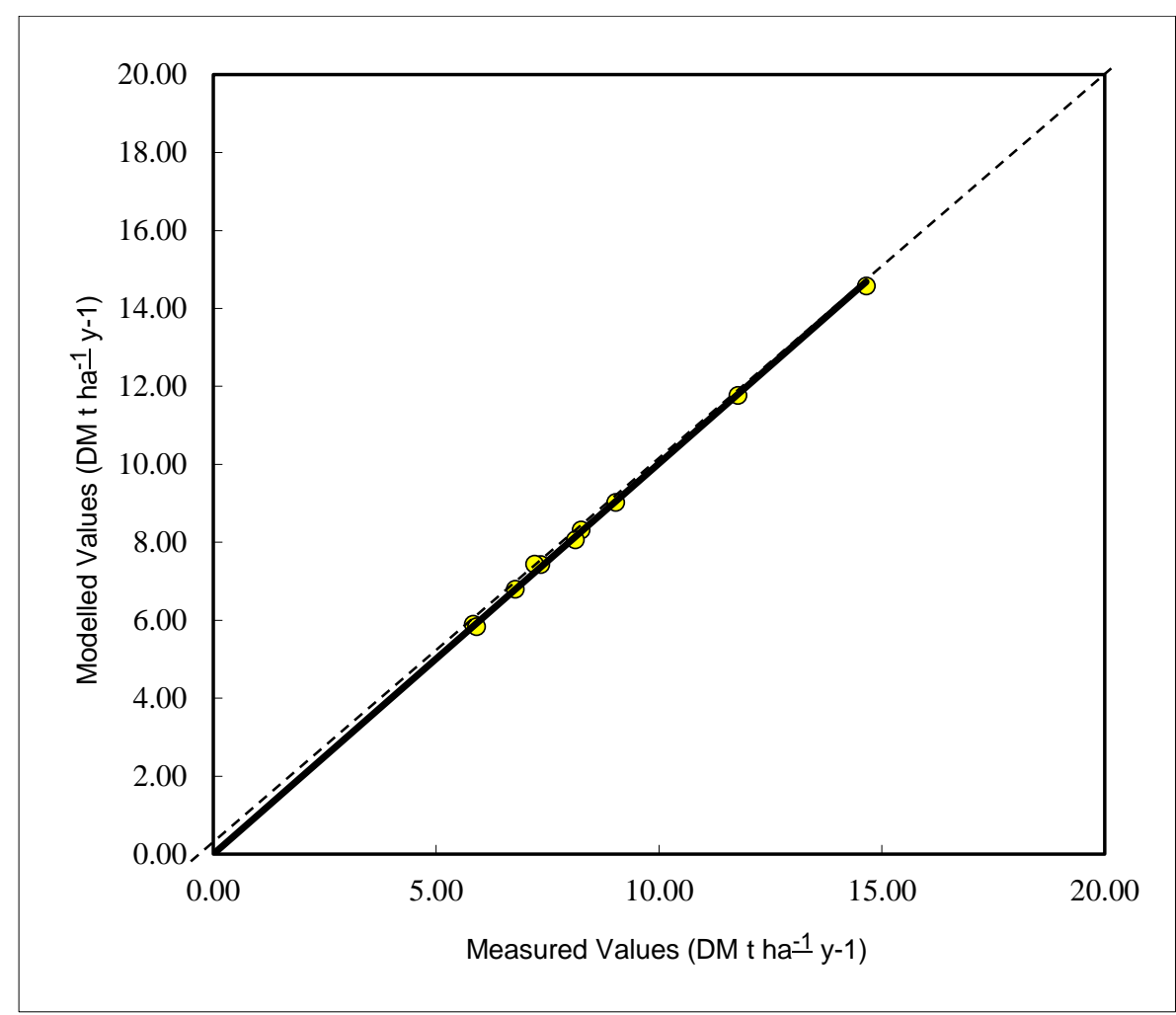

Fig. 8: A comparison of measured and modelled yield on all intensive sites shows that PopFor can simulate these yields well. 


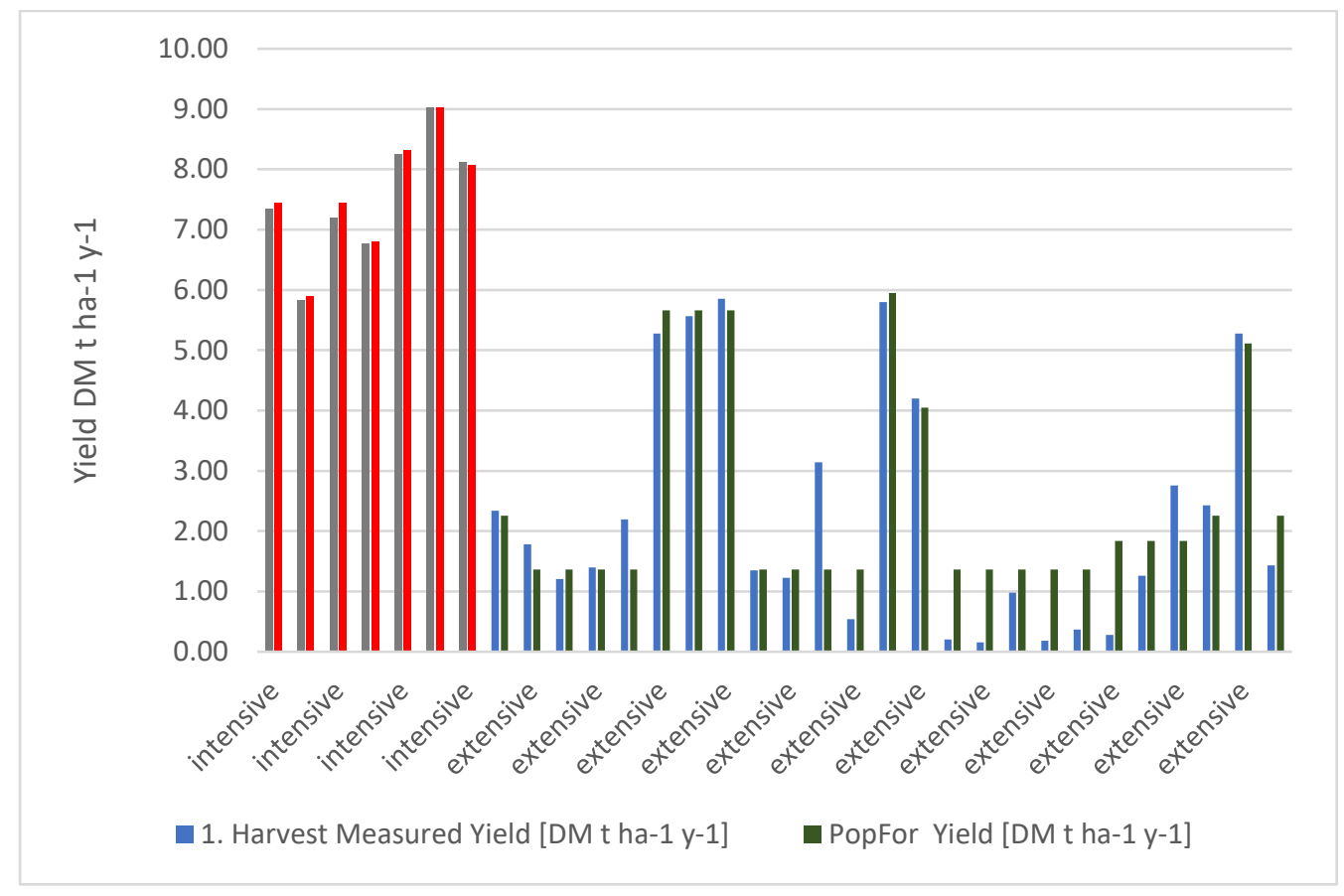

Fig. 9: Comparison of 1st rotation extensive against intensive measured yields over all BIODEM sites.

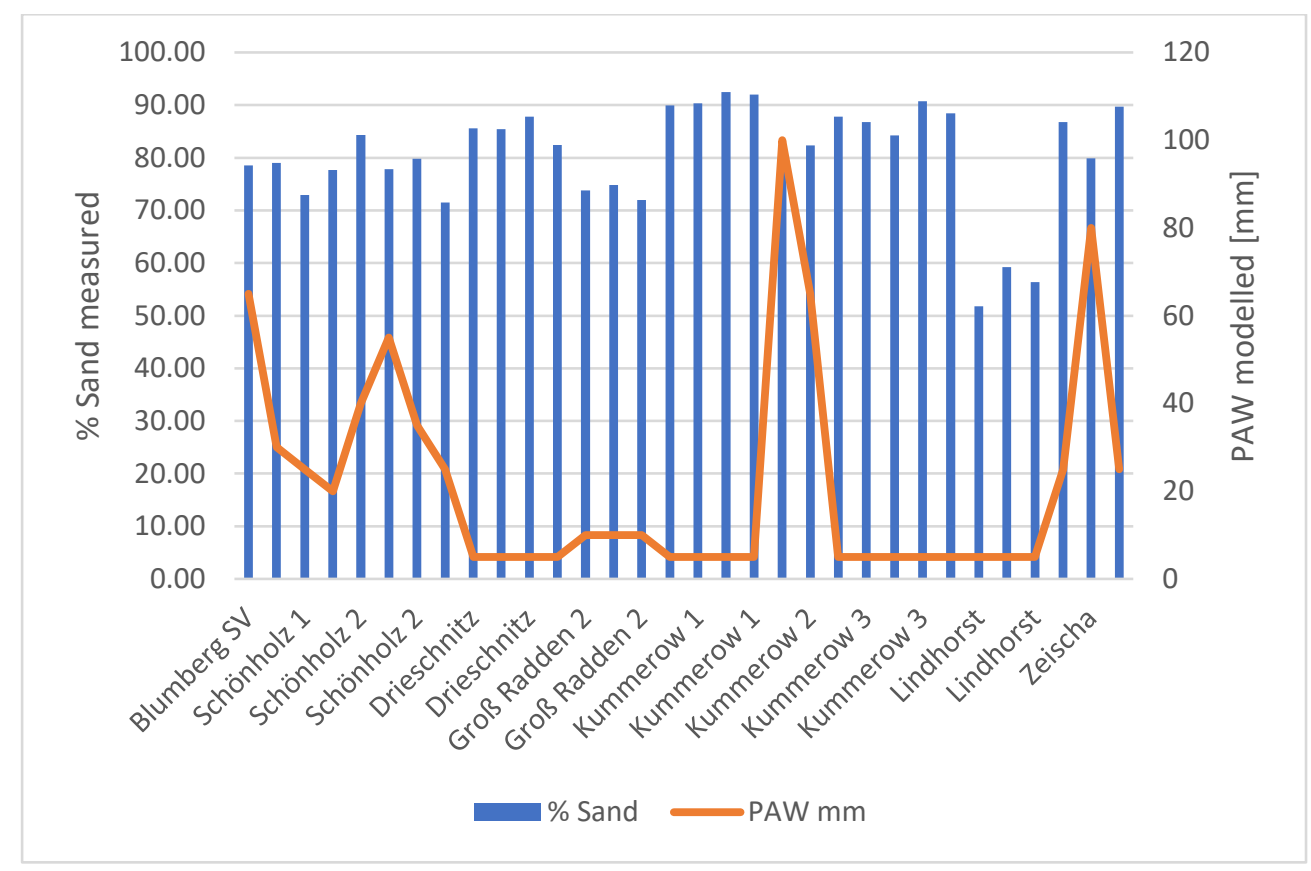

Fig. 10: Visualisation of the percent sand and PAW values over all 1st harvest sites.

\subsection{Model performance at independent evaluation sites}


Modelling multiple sites in Europe for an independent validation of PopFor model results demonstrated that potential yields are consistent with measured data from sites in Brandenburg, Germany [55,85]. Other sites in Belgium [8,11], Italy [5,12,91], the UK [3,21,92,93], Denmark [11,14,94], Czech Republic [95] and Austria [personal communication]. The measured and modelled poplar yields are compared in Fig. 11 and table A2. The mean yield for all the sample sites in Europe in Table A2 is $9.07 \mathrm{DM} \mathrm{tha}^{-1} \mathrm{y}^{-1}$, which corresponds well with the PopFor mean yields of 9.5 DM tha $\mathrm{DH}^{-1}$. A linear regression gives a unity relationship with an $\mathrm{r}^{2}=0.99(\mathrm{n} 230, \mathrm{~F}=3.88, \mathrm{p}<0.05$ with $\mathrm{RMSE}=17.28 \%$, twotailed students t-test is 1.97 with a mean difference of $0.43 \mathrm{DM} \mathrm{tha}^{-1} \mathrm{y}^{-1}$ ) for the poplar results. Statistical analysis confirms that there is a significant association, no significant bias and no significant error between measured and modelled yield results.

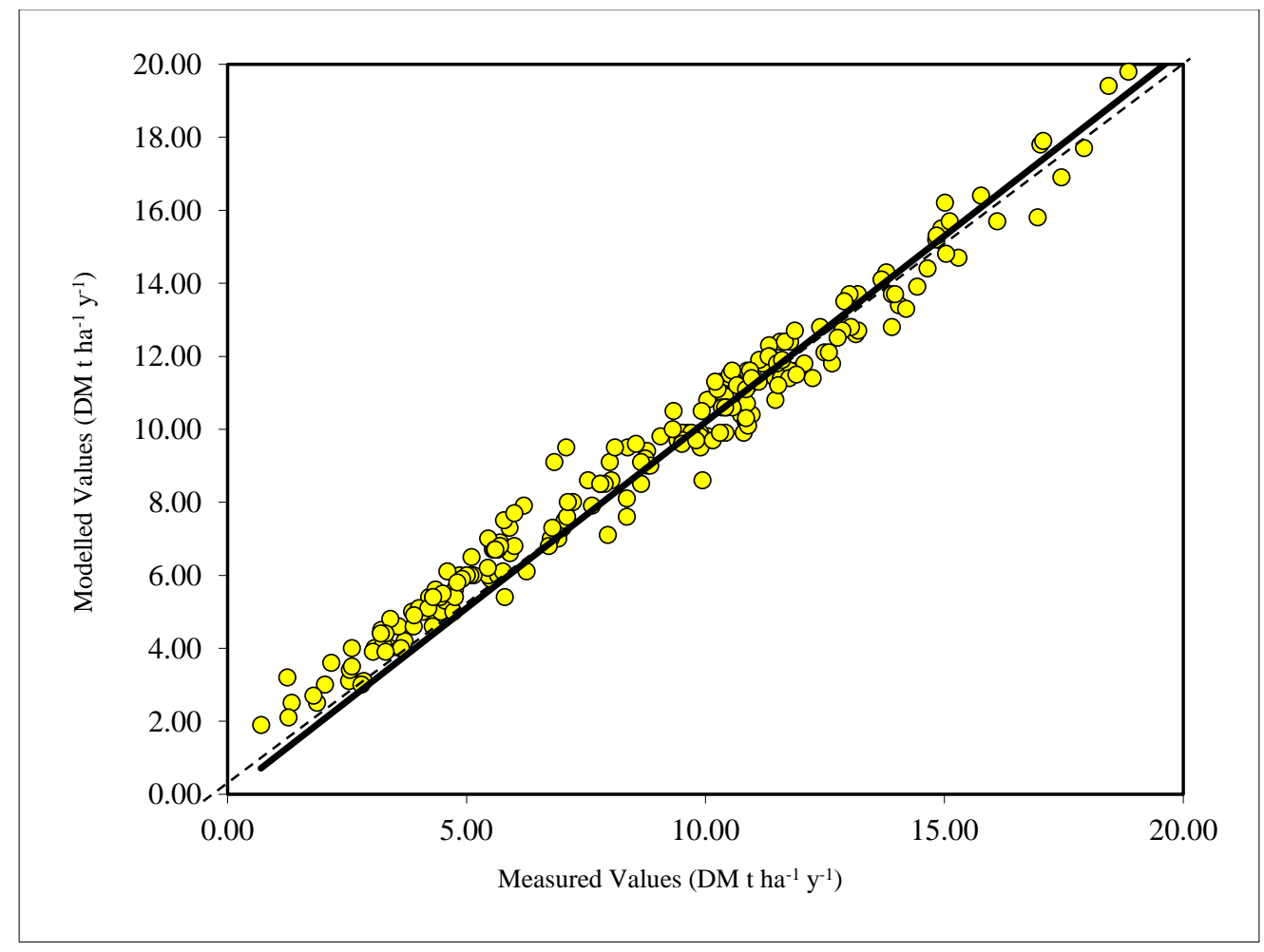

Fig. 11: Independent evaluation of PopFor modelled yields against measured yields on different sites all over Europe confirms that PopFor is widely applicable.

\section{Discussion}

\subsection{Parameterisation}


The results (Table 5) show that the model simulates the measured yield of established poplar accurately with a mean difference of $0.26 \mathrm{DM} \mathrm{tha}^{-1} \mathrm{y}^{-1}$ (SD for measured yield 5.2, SD for modelled yield 4.94). PopFor was parameterised to model the yields of well-established and managed poplar plantations at $2^{\text {nd }}$ rotation and can do so accurately without any changes to either PAW or RUE. To predict all yields, either first or second rotation, irrespective of the soil conditions and using the same climate data, only the value for PAW needs to be changed. This implies that the PopFor model captures most of the poplar physiology. In order to predict yields in any one site, good knowledge of PAW, evaporation/precipitation balance and access to groundwater is the prerequisite for considering the establishment of a commercial plantation for coppicing. The model can simulate yields in Germany, on the same order as those found all over Europe in commercial plantations (Table A2, section 4.2). For established plants, European yields between $9 \mathrm{DM} \mathrm{tha}^{-1} \mathrm{y}^{-1}$ and $15 \mathrm{DM} \mathrm{tha}^{-1} \mathrm{y}^{-1}$ are published widely $[3,5,8,11,12,14,21,85,91-95,98]$. In Northern Italy, on optimum sites, yields can reach values around $20 \mathrm{DM} \mathrm{tha}^{-1} \mathrm{y}^{-1}[5,12,91,98]$. This is mostly caused by warmer temperatures and higher rates of sunshine as long as there is no limitation of PAW and when suitable poplar genotypes are used $[5,12,91,98]$. At the BIODEM sites used during this PopFor parameterisation, the Lindhorst site showed the same behaviour. The soil was suitable with only $51 \%$ sand and the poplar could reach groundwater after establishment. As a result, the yields at this site increased up to $21 \mathrm{DM} \mathrm{tha}^{-1} \mathrm{y}^{-1}$ which could be followed by PopFor when maximum RUE was adjusted to $4.5 \mathrm{~g} \mathrm{MJ}^{-1}$. This is again in accordance with published findings which confirm that the poplar plant partitioning between above ground and below ground biomass changes when the plant has constant PAW [8,14,60,70,71]. As a consequence, as the model only calculates above ground biomass as the below ground biomass of woody perennials is seldom measured and the focus of the model is to predict harvestable biomass yields, RUE values in very well-established plants are higher than in less developed poplar plants, due to the effect of higher leaf and stem biomass. 
In the case of the Brandenburg experimental plots, setting the correct value for PAW enables the model to match all the experimental yields accounting for the variability in the soil texture and depth. This demonstrated that at these sites, the most limiting factor for poplar growth is available water. Brandenburg is an area with low rainfall (average $375 \mathrm{~mm} \mathrm{y}^{-1}$ ). Reduced water availability can increase investment in roots bringing low groundwater tables into reach for established Populus plants, although this generally occurs when plants are subjected to severe drought stress, which does happen at some BIODEM sites, and total biomass is severely reduced over the whole plant lifecycle which can be observed at many BIODEM sites $[6,8,55,60,70,72,85,99]$.

In the establishment years of 2007 and 2008, an extreme spring drought impacted the experiments [85]. To overcome this, plants were irrigated at the beginning. Some sites developed into well-established crops by the $2^{\text {nd }}$ rotation, others never managed to reach the groundwater which resulted in continuously low water limited yields or plant death (Fig. 12). Several plots in this figure at Kummerow 1 site show severe plant death due to drought condition. Previous studies in Populus species showed that performance during early life history stages plays a critical role in determining individuals' lifetime fitness, because young plants are much more sensitive to drought and flooding than adult plants $[55,70,80,99-102]$. Total dry mass over the plant life is severely reduced under continuous drought, but on the other hand continuous flooding would reduce the total dry mass as well. This effect is relatively unimpacted by genotype $[66,80,101,102]$. 


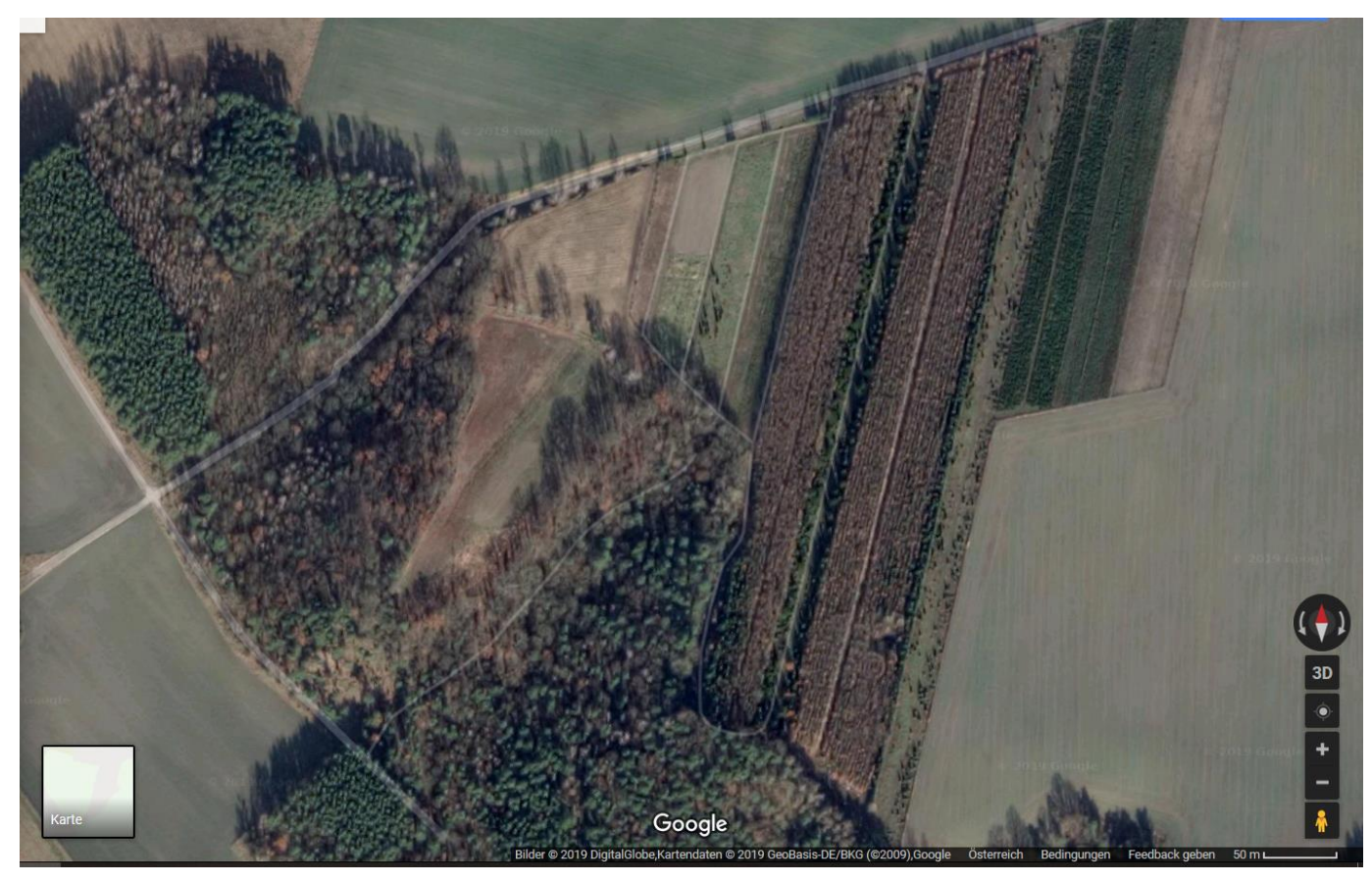

Fig. 12: Kummerow 1 site is a good example for poplar drought death due to bad soil conditions and lack of water access. (GeoBasis DE/BKG, Google)

When it comes to spring or winter frosts, the sensitivity of different poplar genotypes is inhomogeneous and closely linked with the poplar family they are based on. This is closely linked with how early or late a genotype starts to grow leaves and blooms [70,83,84,103]. Members of the aspen family are normally among the late starters and therefore very much adapted to climates with large temperature fluctuations in winter and spring. Poplar has been shown to be very frost hardy once the starch in the plant tissue, especially the xylem, has been converted to sugar. This process usually starts with the first autumn frost around $-1{ }^{\circ} \mathrm{C}$ to -5 ${ }^{\circ} \mathrm{C}$ and allows the poplar to grow in very cold climates $[71,83,84,103]$.

Testing of intensive and extensive managed sites has shown that good management during establishment phase is extremely important to generate economically viable poplar yields, even more so than for Willow [8,11]. At very low yielding sites, competition by weeds is an issue. Subsequently, the already very low yields modelled (around $4 \mathrm{DM}$ ha $\mathrm{y}^{-1}$ ) are not realised at these sites because the impaired growth of poplar is so slow that competition from 
weeds for available resources, especially water, becomes a lethally growth inhibiting factor. Poplar should be treated as a valuable crop with intensive management during establishment in order to keep yields at the maximum level possible based on the weather and soil conditions. It does not make sense to grow it without careful establishment management because the yields will be detrimental, and plants mostly stay under their potential at the respective sites $[8,11,12,63,74,79,99]$.

Other site factors not included in the model, e.g. topography, pests and weeds, can also lead to impacts which could reduce yields further and would not be included in the model $[12,104-$ 106].

\subsection{Independent evaluation}

The independent evaluation of PopFor model results with measured data from sites in Europe (Brandenburg, Germany [55,85]; Belgium [8,11], Italy [5,12,91], the UK [3,21,92,93], Denmark [11,63,94], Czech Republic [95] and Austria [personal communication]) has confirmed that PopFor is well parameterised and widely applicable (Table A2). The overall yield for all the sample sites in Europe in Table A2 is slightly lower than the modelled yield (9.07 DM t ha ${ }^{-1} \mathrm{y}^{-1}$ measured against 9.5 $\mathrm{DM} \mathrm{tha}^{-1} \mathrm{y}^{-1}$ modelled). This confirms that PopFor results are widely applicable. The results are most accurate when the crops are managed well or in a suitable location when poplar produces yields in the range of $9 \mathrm{DM} \mathrm{tha}^{-1} \mathrm{y}^{-1}$ to $13 \mathrm{DM}$ $\mathrm{t} \mathrm{ha}^{-1} \mathrm{y}^{-1}$ in which case no changes in the model are needed. As shown before, PopFor results for very poorly performing crops overshoot somewhat, even when PAW is adjusted. On the other hand, in areas where poplar grows exceptionally well, reaching yields above $22 \mathrm{DM} \mathrm{t}$ $\mathrm{ha}^{-1} \mathrm{y}^{-1}$, PopFor cannot follow these data unless the PAW and in some cases RUE is changed to reflect constant groundwater access in addition to otherwise perfect growth conditions. 
There are several published research results $[10,55,70,77,85,107-110]$ available for other sites in Germany with a climate and soil comparable to the BIODEM sites used in this research and the range of yields varies between $2 \mathrm{DM} \mathrm{tha}^{-1} \mathrm{y}^{-1}$ and $19 \mathrm{DM} \mathrm{tha}^{-1} \mathrm{y}^{-1}$. As the sites are quite different, the relatively dry climate in Germany might explain the reduced yields, which is also confirmed by other published studies which demonstrates that BIODEM results are typical for Germany $[10,85,108]$.

\subsection{Findings in the context of previous studies}

The importance of water availability observed in this study has been found by field measurements in previous studies $[6,55,66,74,78,80,85,99,101,111]$. Previous research showed a clear correlation between precipitation or groundwater access and yield $[6,12,14,91,99]$ and confirmed the importance of water availability to achieve high poplar yields. As the groundwater level on the BIODEM sites is often very deep below rooting depth, sites like Lindhorst, where yields of $21 \mathrm{DM} \mathrm{tha}^{-1} \mathrm{y}^{-1}$ were measured, must have access to groundwater. At Lindhorst, site soil conditions were close to optimal, none the less establishment was very slow with yields under $3 \mathrm{DM} \mathrm{tha}^{-1} \mathrm{y}^{-1}$ during first harvest before peaking at $21 \mathrm{DM} \mathrm{tha}^{-1} \mathrm{y}^{-1}$ during second harvest (Table). The large water retention capacity of the soil made up for lack of constant groundwater access and drought. The importance of soil for high poplar yields becomes obvious when looking at adjacent sites like Cahnsdorf, with $1^{\text {st }}$ harvest yield of $2.34 \mathrm{DM} \mathrm{tha} \mathrm{D}^{-1} \mathrm{y}^{-1}$ and Gross Radden which had $1^{\text {st }}$ harvest yields between 2.19 DM that $\mathrm{y}^{-1}$ and 5.85 DM that $\mathrm{y}^{-1}$. None the less, one Gross Radden plot could not establish even for $2^{\text {nd }}$ harvest which indicates large soil and PAW differences within the sites (Table). The only noted differences between Gross Radden and Cahnsdorf sites is the difference in bulk density, $1.33 \mathrm{~g} \mathrm{~cm}^{3}$ and $1.47 \mathrm{~g} \mathrm{~cm}^{3}$ in Gross Radden compared with $1.80 \mathrm{~g}$ $\mathrm{cm}^{3}$ and $1.85 \mathrm{~g} \mathrm{~cm}^{3}$ in the Cahnsdorf plots and the difference in organic carbon in the soils: $0.50 \%$ and $0.62 \%$ at Cahnsdorf and $2.21 \%$ and $3.61 \%$ at the Gross Radden sites. There can be 
other factors having an impact on these different yields, like topography or different ground water table, but the area is very flat, and no adjacent waterbodies are visible.

Different poplar clones differ widely in LAI, $\mathrm{N}$ use, soil and water sensitivity $[8,54,62,66,112]$. It is important to state that PopFor was parameterised and tested with data on Max 1, Max 3 and Max 4, and is therefore modelling potential yield for clones similar to these adaptable and high yielding clones. It can be assumed that the above-mentioned physiological parameters that are represented in PopFor based on the data used for parameterisation will be similar to other high performing clones, but this was not part of this research. Following on from this research, we intend to test the PopFor model with different clones and areas and prepare a spatial version.

\subsection{Poplar models}

PopFor can predict potential yields based on soil and climate data available only for several areas in Europe. This small amount of input variables needed makes it a useful tool for assessing potential yields in any given area. Most other poplar models need diameter, height and stem number as input variables $[92,93]$. Based on these parameters, a regression can be used to determine the potential poplar yields on a spatial scale. Some models, like PRISMELM $[113,114]$, approach the question from another angle. PRISM-ELM uses a regression equation based on the degree of suitability for a specific crop in a given area of the USA. As PRISM-ELM is solely based on suitability maps from the USA, the results are not yet applicable in other countries.

\section{Conclusions}

PopFor is accurate at predicting yield for established Populus crops or intensively managed and well-established poplar plants during all plant life stages, especially with high performing clones. PopFor estimates the potential yield over all sites, irrespective the site management 
and soil conditions, very well when the PAW is matched to the site conditions. In order to improve the ability of the PopFor model to predict spatial yields, a knowledge of groundwater accessibility should be included in the model, which requires a suitable spatial data set of groundwater level at the resolution at which the model is used. At present, only soil hydraulic properties and the balance between rainfall and evapotranspiration are available and used. Plant available water is one of the most important factors for strong poplar growth $[55,70,80,100-102,109]$. On the other hand, lack of water due to lack of precipitation or low water holding capacities in sandy soils without access to groundwater does not allow poplar to establish in the soil $[6,14,55,85,99,115]$. Root growth is restricted, unless severe drought is constant in which case root growth can be intensified, and yields are consequently very low $[14,55,70,72,85,99]$. It has been shown that performance of Populus species during early life stages plays a critical role in determining the lifetime fitness, because young plants are much more sensitive to drought and flooding than adult plants [11,70,85,99-102]. It would be interesting to define a correlation between early stage growth, the partitioning of plant biomass at different stages and conditions and the yields given by established plants so that PopFor performance can be improved for establishment phase and for extremely wellestablished poplar plants. PopFor was parameterised to determine potential yield from commercial poplar bioenergy plantations all over Europe to determine the general suitability of poplar as a bioenergy crop long before planting. Independent sensitivity analysis of modelled yields against published measured yields has shown that PopFor can predict yields in different areas accurately. Best results are achieved for poplar in good growth conditions with yields around the mean European yields of 9.07 DM tha-1 $\mathrm{y}^{-1}$.

\section{Acknowledgements}

Yield and soil data for this project has been supplied by Rainer Schlepphorst, Holger Hartmann and Dieter Murach from HNEE, Germany, from the BIODEM project. Soil water 
and groundwater data were supplied by Markus Schmidt, HNEE, Germany. We would like to

thank Shell and the University of Aberdeen CLSM for funding this work with a studentship.

The MiscanFor modelling was supported by UK NERC ADVENT (NE/1806209) and FAB-

GGR (NE/P019951/1) project funding.

\section{References}

[1] A. Hastings, J. Clifton-Brown, M. Wattenbach, C.P. Mitchell, P. Smith, The development of MISCANFOR, a new Miscanthus crop growth model: towards more robust yield predictions under different climatic and soil conditions, GCB Bioenergy. 1 (2009) 154-170. https://doi.org/10.1111/j.1757-1707.2009.01007.x.

[2] A. Hastings, J. Clifton-Brown, M. Wattenbach, C.P. Mitchell, P. Stampfl, P. Smith, Future energy potential of Miscanthus in Europe, GCB Bioenergy. 1 (2009) 180-196. https://doi.org/10.1111/j.1757-1707.2009.01012.x.

[3] A. Hastings, M.J. Tallis, E. Casella, R.W. Matthews, P.A. Henshall, S. Milner, P. Smith, G. Taylor, The technical potential of Great Britain to produce ligno-cellulosic biomass for bioenergy in current and future climates, GCB Bioenergy. 6 (2014) 108122. https://doi.org/10.1111/gcbb.12103.

[4] D.N. Henner, The potential for second-generation bioenergy crops in Europe and their impact on soil carbon changes and erosion., PhD Thesis, University of Aberdeen, 2019.

[5] S. Bergante, M. Manzone, G. Facciotto, Alternative planting method for short rotation coppice with poplar and willow, Biomass Bioenergy. 87 (2016) 39-45. https://doi.org/10.1016/j.biombioe.2016.02.016.

[6] J. Bloemen, R. Fichot, J.A. Horemans, L.S. Broeckx, M.S. Verlinden, T. Zenone, R. Ceulemans, Water use of a multigenotype poplar short-rotation coppice from tree to stand scale, GCB Bioenergy. (2016) n/a-n/a. https://doi.org/10.1111/gcbb.12345.

[7] H. Borkowska, R. Molas, Yield comparison of four lignocellulosic perennial energy crop species, Biomass Bioenergy. 51 (2013) 145-153. https://doi.org/10.1016/j.biombioe.2013.01.017.

[8] L. Broeckx, S. Vanbeveren, M. Verlinden, R. Ceulemans, First vs. second rotation of a poplar short rotation coppice: leaf area development, light interception and radiation use efficiency, IForest - Biogeosciences For. 8 (2015) 565-573. https://doi.org/10.3832/ifor1457-008.

[9] S. Pereira, M. Costa, M. da Graça Carvalho, A. Rodrigues, Potential of poplar short rotation coppice cultivation for bioenergy in Southern Portugal, Energy Convers. Manag. 125 (2016) 242-253. https://doi.org/10.1016/j.enconman.2016.03.068.

[10] P. Schmidt-Walter, N.P. Lamersdorf, Biomass Production with Willow and Poplar Short Rotation Coppices on Sensitive Areas - the Impact on Nitrate Leaching and Groundwater Recharge in a Drinking Water Catchment near Hanover, Germany, BioEnergy Res. 5 (2012) 546-562. https://doi.org/10.1007/s12155-012-9237-8.

[11] M.S. Verlinden, L.S. Broeckx, R. Ceulemans, First vs. second rotation of a poplar short rotation coppice: Above-ground biomass productivity and shoot dynamics, Biomass Bioenergy. 73 (2015) 174-185. https://doi.org/10.1016/j.biombioe.2014.12.012.

[12] S. Bergante, G. Facciotto, G. Minotta, Identification of the main site factors and management intensity affecting the establishment of Short-Rotation-Coppices (SRC) in Northern Italy through stepwise regression analysis, Cent. Eur. J. Biol. 5 (2010) 522530. https://doi.org/10.2478/s11535-010-0028-y. 
[13] R. Ceulemans, W. Deraedt, Production physiology and growth potential of poplars under short-rotation forestry culture, For. Ecol. Manag. 121 (1999) 9-23. https://doi.org/10.1016/S0378-1127(98)00564-7.

[14] M.S. Verlinden, L.S. Broeckx, J. Van den Bulcke, J. Van Acker, R. Ceulemans, Comparative study of biomass determinants of 12 poplar (Populus) genotypes in a high-density short-rotation culture, For. Ecol. Manag. 307 (2013) 101-111. https://doi.org/10.1016/j.foreco.2013.06.062.

[15] J.N. Barney, Bioenergy and Invasive Plants: Quantifying and Mitigating Future Risks, Invasive Plant Sci. Manag. 7 (2014) 199-209. https://doi.org/10.1614/IPSM-D-1300060.1 .

[16] S.C. de Vries, G.W.J. van de Ven, M.K. van Ittersum, First or second generation biofuel crops in Brandenburg, Germany? A model-based comparison of their production-ecological sustainability, Eur. J. Agron. 52 (2014) 166-179. https://doi.org/10.1016/j.eja.2013.09.012.

[17] U. Jørgensen, Benefits versus risks of growing biofuel crops: the case of Miscanthus, Curr. Opin. Environ. Sustain. 3 (2011) 24-30. https://doi.org/10.1016/j.cosust.2010.12.003.

[18] K.C. Lewis, R.D. Porter, Global approaches to addressing biofuel-related invasive species risks and incorporation into U.S. laws and policies, Ecol. Monogr. 84 (2014) 171-201. https://doi.org/10.1890/13-1625.1.

[19] F. Creutzig, A. Popp, R. Plevin, G. Luderer, J. Minx, O. Edenhofer, Reconciling topdown and bottom-up modelling on future bioenergy deployment, Nat. Clim. Change. 2 (2012) 320-327. https://doi.org/10.1038/nclimate1416.

[20] F. Creutzig, N.H. Ravindranath, G. Berndes, S. Bolwig, R. Bright, F. Cherubini, H. Chum, E. Corbera, M. Delucchi, A. Faaij, J. Fargione, H. Haberl, G. Heath, O. Lucon, R. Plevin, A. Popp, C. Robledo-Abad, S. Rose, P. Smith, A. Stromman, S. Suh, O. Masera, Bioenergy and climate change mitigation: an assessment, GCB Bioenergy. (2014) n/a-n/a. https://doi.org/10.1111/gcbb.12205.

[21] M. Richards, M. Pogson, M. Dondini, E.O. Jones, A. Hastings, D.N. Henner, M.J. Tallis, E. Casella, R.W. Matthews, P.A. Henshall, S. Milner, G. Taylor, N.P. McNamara, J.U. Smith, P. Smith, High-resolution spatial modelling of greenhouse gas emissions from land-use change to energy crops in the United Kingdom, GCB Bioenergy. 9 (2017) 627-644. https://doi.org/10.1111/gcbb.12360.

[22] R.E.H. Sims, A.F.S.J. Hastings, B. Schlamadinger, G. Taylor, P. Smith, Energy crops: current status and future prospects, Glob. Change Biol. 12 (2006) 2054-2076. https://doi.org/10.1111/j.1365-2486.2006.01163.x.

[23] P. Smith, C.A. Davies, S. Ogle, G. Zanchi, J. Bellarby, N. Bird, R.M. Boddey, N.P. McNamara, D. Powlson, A. Cowie, M. Noordwijk, S.C. Davis, D.D.B. Richter, L. Kryzanowski, M.T. Wijk, J. Stuart, A. Kirton, D. Eggar, G. Newton-Cross, T.K. Adhya, A.K. Braimoh, Towards an integrated global framework to assess the impacts of land use and management change on soil carbon: current capability and future vision, Glob. Change Biol. 18 (2012) 2089-2101. https://doi.org/10.1111/j.13652486.2012.02689.x.

[24] T. Beringer, W. Lucht, S. Schaphoff, Bioenergy production potential of global biomass plantations under environmental and agricultural constraints, GCB Bioenergy. 3 (2011) 299-312. https://doi.org/10.1111/j.1757-1707.2010.01088.x.

[25] R. Slade, A. Bauen, R. Gross, Global bioenergy resources, Nat. Clim. Change. 4 (2014) 99-105. https://doi.org/10.1038/nclimate2097.

[26] J. Clifton-Brown, A. Harfouche, M.D. Casler, H.D. Jones, W.J. Macalpine, D. MurphyBokern, L.B. Smart, A. Adler, C. Ashman, D. Awty-Carroll, C. Bastien, S. Bopper, V. Botnari, M. Brancourt-Hulmel, Z. Chen, L.V. Clark, S. Cosentino, S. Dalton, C. Davey, 
O. Dolstra, I. Donnison, R. Flavell, J. Greef, S. Hanley, A. Hastings, M. Hertzberg, T.W. Hsu, L.S. Huang, A. Iurato, E. Jensen, X. Jin, U. Jørgensen, A. Kiesel, D.-S. Kim, J. Liu, J.P. McCalmont, B.G. McMahon, M. Mos, P. Robson, E.J. Sacks, A. Sandu, G. Scalici, K. Schwarz, D. Scordia, R. Shafiei, I. Shield, G. Slavov, B.J. Stanton, K. Swaminathan, G. Taylor, A.F. Torres, L.M. Trindade, T. Tschaplinski, G.A. Tuskan, T. Yamada, C.Y. Yu, R.S. Zalesny, J. Zong, I. Lewandowski, Breeding progress and preparedness for mass-scale deployment of perennial lignocellulosic biomass crops switchgrass, miscanthus, willow and poplar, GCB Bioenergy. 11 (2019) 118-151. https://doi.org/10.1111/gcbb.12566.

[27] J.P. McCalmont, A. Hastings, N.P. McNamara, G.M. Richter, P. Robson, I.S. Donnison, J. Clifton-Brown, Environmental costs and benefits of growing Miscanthus for bioenergy in the UK, GCB Bioenergy. (2015) n/a-n/a. https://doi.org/10.1111/gcbb.12294.

[28] S. Milner, A. Lovett, R.A. Holland, G. Sunnenberg, A. Hastings, P. Smith, G. Taylor, A preliminary assessment of the ecosystem service impacts of bioenergy in GB to 2050, Glob. Change Biol.-Bioenergy. available online (2015).

[29] J. Valentine, J. Clifton-Brown, A. Hastings, P. Robson, G. Allison, P. Smith, Food vs. fuel: the use of land for lignocellulosic 'next generation' energy crops that minimize competition with primary food production, GCB Bioenergy. 4 (2012) 1-19. https://doi.org/10.1111/j.1757-1707.2011.01111.x.

[30] A.E. Farrell, R.J. Plevin, B.T. Turner, A.D. Jones, M. O’Hare, D.M. Kammen, Ethanol can contribute to energy and environmental goals, Science. 311 (2006) 506-508. https://doi.org/10.1126/science.1121416.

[31] A. Hastings, J. Yeluripati, J. Hillier, P. Smith, Biofuel Crops and Greenhouse Gases, in: B.P. Singh (Ed.), Biofuel Crop Sustain., John Wiley \& Sons, Ltd, 2013: pp. 383-405. http://onlinelibrary.wiley.com/doi/10.1002/9781118635797.ch12/summary (accessed April 16, 2016).

[32] A. Hastings, M. Mos, J.A. Yesufu, J. McCalmont, K. Schwarz, R. Shafei, C. Ashman, C. Nunn, H. Schuele, S. Cosentino, G. Scalici, D. Scordia, M. Wagner, J. CliftonBrown, Economic and Environmental Assessment of Seed and Rhizome Propagated Miscanthus in the UK, Front. Plant Sci. 8 (2017). https://doi.org/10.3389/fpls.2017.01058.

[33] B. Mola-Yudego, P. Aronsson, Yield models for commercial willow biomass plantations in Sweden, Biomass Bioenergy. 32 (2008) 829-837. https://doi.org/10.1016/j.biombioe.2008.01.002.

[34] P. Smith, Soil carbon sequestration and biochar as negative emission technologies, Glob. Change Biol. 22 (2016) 1315-1324. https://doi.org/10.1111/gcb.13178.

[35] F. Creutzig, N.H. Ravindranath, G. Berndes, S. Bolwig, R. Bright, F. Cherubini, H. Chum, E. Corbera, M. Delucchi, A. Faaij, J. Fargione, H. Haberl, G. Heath, O. Lucon, R. Plevin, A. Popp, C. Robledo-Abad, S. Rose, P. Smith, A. Stromman, S. Suh, O. Masera, Bioenergy and climate change mitigation: an assessment, GCB Bioenergy. 7 (2015) 916-944. https://doi.org/10.1111/gcbb.12205.

[36] C. Robledo-Abad, H.-J. Althaus, G. Berndes, S. Bolwig, E. Corbera, F. Creutzig, J. Garcia-Ulloa, A. Geddes, J.S. Gregg, H. Haberl, S. Hanger, R.J. Harper, C. Hunsberger, R.K. Larsen, C. Lauk, S. Leitner, J. Lilliestam, H. Lotze-Campen, B. Muys, M. Nordborg, M. Ölund, B. Orlowsky, A. Popp, J. Portugal-Pereira, J. Reinhard, L. Scheiffle, P. Smith, Bioenergy production and sustainable development: science base for policymaking remains limited, GCB Bioenergy. 9 (2017) 541-556. https://doi.org/10.1111/gcbb.12338. 
[37] F. Creutzig, Economic and ecological views on climate change mitigation with bioenergy and negative emissions, GCB Bioenergy. 8 (2016) 4-10. https://doi.org/10.1111/gcbb.12235.

[38] D. Klein, G. Luderer, E. Kriegler, J. Strefler, N. Bauer, M. Leimbach, A. Popp, J.P. Dietrich, F. Humpenöder, H. Lotze-Campen, O. Edenhofer, The value of bioenergy in low stabilization scenarios: an assessment using REMIND-MAgPIE, Clim. Change. 123 (2013) 705-718. https://doi.org/10.1007/s10584-013-0940-z.

[39] F. Kraxner, K. Aoki, S. Leduc, G. Kindermann, S. Fuss, J. Yang, Y. Yamagata, K.-I. Tak, M. Obersteiner, BECCS in South Korea-Analyzing the negative emissions potential of bioenergy as a mitigation tool, Renew. Energy. 61 (2014) 102-108. https://doi.org/10.1016/j.renene.2012.09.064.

[40] M. Muratori, K. Calvin, M. Wise, P. Kyle, J. Edmonds, Global economic consequences of deploying bioenergy with carbon capture and storage (BECCS), Environ. Res. Lett. 11 (2016) 095004. https://doi.org/10.1088/1748-9326/11/9/095004.

[41] P. Smith, S.J. Davis, F. Creutzig, S. Fuss, J. Minx, B. Gabrielle, E. Kato, R.B. Jackson, A. Cowie, E. Kriegler, D.P. van Vuuren, J. Rogelj, P. Ciais, J. Milne, J.G. Canadell, D. McCollum, G. Peters, R. Andrew, V. Krey, G. Shrestha, P. Friedlingstein, T. Gasser, A. Grübler, W.K. Heidug, M. Jonas, C.D. Jones, F. Kraxner, E. Littleton, J. Lowe, J.R. Moreira, N. Nakicenovic, M. Obersteiner, A. Patwardhan, M. Rogner, E. Rubin, A. Sharifi, A. Torvanger, Y. Yamagata, J. Edmonds, C. Yongsung, Biophysical and economic limits to negative CO2 emissions, Nat. Clim. Change. 6 (2016) 42-50. https://doi.org/10.1038/nclimate2870.

[42] O. Edenhofer, K. Seyboth, F. Creutzig, S. Schlömer, On the Sustainability of Renewable Energy Sources, Annu. Rev. Environ. Resour. 38 (2013) 169-200. https://doi.org/10.1146/annurev-environ-051012-145344.

[43] V. Heck, D. Gerten, W. Lucht, A. Popp, Biomass-based negative emissions difficult to reconcile with planetary boundaries, Nat. Clim. Change. 8 (2018) 151. https://doi.org/10.1038/s41558-017-0064-y.

[44] J. Cunniff, S.J. Purdy, T.J.P. Barraclough, M. Castle, A.L. Maddison, L.E. Jones, I.F. Shield, A.S. Gregory, A. Karp, High yielding biomass genotypes of willow (Salix spp.) show differences in below ground biomass allocation, Biomass Bioenergy. 80 (2015) 114-127. https://doi.org/10.1016/j.biombioe.2015.04.020.

[45] E.S. Fabio, T.A. Volk, R.O. Miller, M.J. Serapiglia, A.R. Kemanian, F. Montes, Y.A. Kuzovkina, G.J. Kling, L.B. Smart, Contributions of environment and genotype to variation in shrub willow biomass composition, Ind. Crops Prod. 108 (2017) 149-161. https://doi.org/10.1016/j.indcrop.2017.06.030.

[46] A. Kiesel, C. Nunn, Y. Iqbal, T. Van der Weijde, M. Wagner, M. Özgüven, I. Tarakanov, O. Kalinina, L.M. Trindade, J. Clifton-Brown, I. Lewandowski, SiteSpecific Management of Miscanthus Genotypes for Combustion and Anaerobic Digestion: A Comparison of Energy Yields, Front. Plant Sci. 8 (2017). https://doi.org/10.3389/fpls.2017.00347.

[47] C. Nunn, A.F.S.J. Hastings, O. Kalinina, M. Özgüven, H. Schüle, I.G. Tarakanov, T. Van Der Weijde, A.A. Anisimov, Y. Iqbal, A. Kiesel, N.F. Khokhlov, J.P. McCalmont, H. Meyer, M. Mos, K.-U. Schwarz, L.M. Trindade, I. Lewandowski, J.C. CliftonBrown, Environmental Influences on the Growing Season Duration and Ripening of Diverse Miscanthus Germplasm Grown in Six Countries, Front. Plant Sci. 8 (2017). https://doi.org/10.3389/fpls.2017.00907.

[48] M.J. Tallis, E. Casella, P.A. Henshall, M.J. Aylott, T.J. Randle, J.I.L. Morison, G. Taylor, Development and evaluation of ForestGrowth-SRC a process-based model for short rotation coppice yield and spatial supply reveals poplar uses water more 
efficiently than willow, GCB Bioenergy. 5 (2013) 53-66.

https://doi.org/10.1111/j.1757-1707.2012.01191.x.

[49] G. Taylor, P.J. Tricker, L.E. Graham, M.J. Tallis, A.M. Rae, H. Trewin, N.R. Street, The Potential of Genomics and Genetics to Understand Plant Response to Elevated Atmospheric [CO2], in: J. Nösberger, S.P. Long, R.J. Norby, M. Stitt, G.R. Hendrey, H. Blum (Eds.), Manag. Ecosyst. CO2 Case Stud. Process. Perspect., Springer Berlin Heidelberg, Berlin, Heidelberg, 2006: pp. 351-371. https://doi.org/10.1007/3-54031237-4_20.

[50] A. Karp, G.M. Richter, I.F. Shield, S.J. Hanley, Genetics, Genomics and Crop Modelling: Integrative Approaches to the Improvement of Biomass Willows, in: M.C. McCann, M.S. Buckeridge, N.C. Carpita (Eds.), Plants BioEnergy, Springer New York, New York, NY, 2014: pp. 107-130. http://link.springer.com/10.1007/978-1-46149329-7_7 (accessed October 26, 2016).

[51] R. Ceulemans, An inventory of tree and stand growth models with potential application in short-rotation forestry, Biomass Bioenergy. 11 (1996) 95-107. https://doi.org/10.1016/0961-9534(96)00018-9.

[52] I. Laureysens, W. Deraedt, T. Indeherberge, R. Ceulemans, Population dynamics in a 6-year old coppice culture of poplar. I. Clonal differences in stool mortality, shoot dynamics and shoot diameter distribution in relation to biomass production, Biomass Bioenergy. 24 (2003) 81-95. https://doi.org/10.1016/S0961-9534(02)00105-8.

[53] A.M. Rae, K.M. Robinson, N.R. Street, G. Taylor, Morphological and physiological traits influencing biomass productivity in short-rotation coppice poplar, Can. J. For. Res. 34 (2004) 1488-1498. https://doi.org/10.1139/x04-033.

[54] M.G.R. Cannell, L.J. Sheppard, R. Milne, Light Use Efficiency and Woody Biomass Production of Poplar and Willow, Forestry. 61 (1988) 125-136. https://doi.org/10.1093/forestry/61.2.125.

[55] J. Hartwich, M. Schmidt, J. Bölscher, C. Reinhardt-Imjela, D. Murach, A. Schulte, Hydrological modelling of changes in the water balance due to the impact of woody biomass production in the North German Plain, Environ. Earth Sci. 75 (2016) 1071. https://doi.org/10.1007/s12665-016-5870-4.

[56] H.G. Jones, Plants and Microclimate: A Quantitative Approach to Environmental Plant Physiology, Cambridge University Press, 1992.

[57] C.W. Thornthwaite, Climate and Moisture Conservation, Ann. Assoc. Am. Geogr. 37 (1947) 87-100. https://doi.org/10.2307/2561023.

[58] H.L. Penman, Natural Evaporation from Open Water, Bare Soil and Grass, 193 (1948) $120-145$.

[59] P.D. Fitzgerald, D.S. Rickard, A comparison of penman's and thornwaite's method of determining soil moisture deficits, N. Z. J. Agric. Res. 3 (1960) 106-112. https://doi.org/10.1080/00288233.1960.10419864.

[60] M.G.R. Cannell, R. Milne, L.J. Sheppard, M.H. Unsworth, Radiation Interception and Productivity of Willow, J. Appl. Ecol. 24 (1987) 261-278. https://doi.org/10.2307/2403803.

[61] M.G.R. Cannell, Physiological basis of wood production: A review, Scand. J. For. Res. 4 (1989) 459-490. https://doi.org/10.1080/02827588909382582.

[62] M.F. Proe, J.H. Griffiths, J. Craig, Effects of spacing, species and coppicing on leaf area, light interception and photosynthesis in short rotation forestry, Biomass Bioenergy. 23 (2002) 315-326. https://doi.org/10.1016/S0961-9534(02)00060-0.

[63] M.S. Verlinden, L.S. Broeckx, D. Zona, G. Berhongaray, T. De Groote, M. Camino Serrano, I.A. Janssens, R. Ceulemans, Net ecosystem production and carbon balance of an SRC poplar plantation during its first rotation, Biomass Bioenergy. 56 (2013) $412-$ 422. https://doi.org/10.1016/j.biombioe.2013.05.033. 
[64] B.Y. Amichev, M. Johnston, K.C.J. Van Rees, Hybrid poplar growth in bioenergy production systems: Biomass prediction with a simple process-based model (3PG), Biomass Bioenergy. 34 (2010) 687-702. https://doi.org/10.1016/j.biombioe.2010.01.012.

[65] P.J. Sands, Process-based Models for Forest Management - Integrating determinants of growth into practical management systems, Coop. Res. Cent. Sustain. Prod. For. CSIRO For. For. Prod. (2003) 30.

[66] J. Ren, W. Dai, Z. Xuan, Y. Yao, H. Korpelainen, C. Li, The effect of drought and enhanced UV-B radiation on the growth and physiological traits of two contrasting poplar species, For. Ecol. Manag. 239 (2007) 112-119. https://doi.org/10.1016/j.foreco.2006.11.014.

[67] J. Renaut, S. Lutts, L. Hoffmann, J.-F. Hausman, Responses of Poplar to Chilling Temperatures: Proteomic and Physiological Aspects, Plant Biol. 7 (2004) 81-90. https://doi.org/10.1055/s-2004-815733.

[68] Agriculture Canada, Growing Degree Days and Crop Production in Canada, 1635/E, Minister of Supply and Services Canada, Ottawa, 1977. http://publications.gc.ca/collections/collection_2013/aac-aafc/agrhist/A53-1635-1977eng.pdf (accessed January 3, 2019).

[69] B.Y. Amichev, R.D. Hangs, N. Bélanger, T.A. Volk, V. Vujanovic, J.J. Schoenau, K.C.J.V. Rees, First-Rotation Yields of 30 Short-Rotation Willow Cultivars in Central Saskatchewan, Canada, BioEnergy Res. 8 (2014) 292-306. https://doi.org/10.1007/s12155-014-9519-4.

[70] M. Schildbach, Untersuchungen zur abiotischen Resistenz von Pappeln, Landbauforsch. - Appl. Agric. For. Res. (2014) 85-98. https://doi.org/10.3220/LBF_2014_85-98.

[71] S.G. Schreiber, A. Hamann, U.G. Hacke, B.R. Thomas, Sixteen years of winter stress: an assessment of cold hardiness, growth performance and survival of hybrid poplar clones at a boreal planting site, Plant Cell Environ. 36 (2013) 419-428. https://doi.org/10.1111/j.1365-3040.2012.02583.x.

[72] W. Nultsch, Allgemeine Botanik, 11th ed., Thieme, Stuttgart New York, 2001.

[73] M. Centritto, F. Brilli, R. Fodale, F. Loreto, Different sensitivity of isoprene emission, respiration and photosynthesis to high growth temperature coupled with drought stress in black poplar (Populus nigra) saplings, Tree Physiol. 31 (2011) 275-286. https://doi.org/10.1093/treephys/tpq112.

[74] G. Di Matteo, P. Nardi, S. Verani, G. Sperandio, Physiological adaptability of Poplar clones selected for bioenergy purposes under non-irrigated and suboptimal site conditions: A case study in Central Italy, Biomass Bioenergy. 81 (2015) 183-189. https://doi.org/10.1016/j.biombioe.2015.06.023.

[75] I. Dimitriou, B. Mola-Yudego, Poplar and willow plantations on agricultural land in Sweden: Area, yield, groundwater quality and soil organic carbon, For. Ecol. Manag. 383 (2017) 99-107. https://doi.org/10.1016/j.foreco.2016.08.022.

[76] G. Fischer, S. Prieler, H. van Velthuizen, Biomass potentials of miscanthus, willow and poplar: results and policy implications for Eastern Europe, Northern and Central Asia, Biomass Bioenergy. 28 (2005) 119-132. https://doi.org/10.1016/j.biombioe.2004.08.013.

[77] K. Lorenz, J. Müller, The Effects of Irrigation on the Growth of Poplars and Willows Cultivated in Short Rotation, in: Bioenergy Dendromass Sustain. Dev. Rural Areas, 2015: pp. 147-160. https://doi.org/10.1002/9783527682973.ch12.

[78] C.A. Souch, W. Stephens, Growth, productivity and water use in three hybrid poplar clones, Tree Physiol. 18 (1998) 829-835. https://doi.org/10.1093/treephys/18.12.829. 
[79] B. Choat, S. Jansen, T.J. Brodribb, H. Cochard, S. Delzon, R. Bhaskar, S.J. Bucci, T.S. Feild, S.M. Gleason, U.G. Hacke, A.L. Jacobsen, F. Lens, H. Maherali, J. MartínezVilalta, S. Mayr, M. Mencuccini, P.J. Mitchell, A. Nardini, J. Pittermann, R.B. Pratt, J.S. Sperry, M. Westoby, I.J. Wright, A.E. Zanne, Global convergence in the vulnerability of forests to drought, Nature. 491 (2012) 752-755. https://doi.org/10.1038/nature11688.

[80] X. Wei, J.A. Savage, C.E. Riggs, J. Cavender-Bares, An experimental test of fitness variation across a hydrologic gradient predicts willow and poplar species distributions, Ecology. 98 (2017) 1311-1323. https://doi.org/10.1002/ecy.1784.

[81] L. Christersson, Wood production potential in poplar plantations in Sweden, Biomass Bioenergy. 34 (2010) 1289-1299. https://doi.org/10.1016/j.biombioe.2010.03.021.

[82] E.A. Hansen, Planting Date Affects Survival and Height Growth of Hybrid Poplar, For. Chron. 62 (1986) 164-169. https://doi.org/10.5558/tfc62164-3.

[83] A. Sakai, Studies of Frost Hardiness in Woody Plants. II. Effect of Temperature on Hardening, Plant Physiol. 41 (1966) 353-359.

[84] A. Sakai, Y. Sugawara, Survival of poplar callus at super-low temperatures after cold acclimation, Plant Cell Physiol. 14 (1973) 1201-1204. https://doi.org/10.1093/oxfordjournals.pcp.a074961.

[85] R. Schlepphorst, H. Hartmann, D. Murach, Versuchsflächen mit schnellwachsenden Baumarten in Brandenburg - Ertragskundliche Ergebnisse für 2006 bis 2015, Yield of fast-growing tree species in northeast Germany: results of research with experimental plots (2006 to 2015), Landbauforsch. Appl. Agric. For. Res. J. Appl. Res. Agric. For. Landbauforsch Appl Agric For. Res. 67 (2017) 93-110. https://doi.org/10.3220/LBF1503914261000.

[86] W. Eckelmann, H. Sponagel, W. Grottenthaler, K.-J. Hartmann, R. Hartwich, P. Janetzko, H. Joisten, D. Kühn, K.-J. Sabel, R. Traidl, Bodenkundliche Kartieranleitung. KA5, (2006).

https://www.schweizerbart.de/publications/detail/isbn/9783510959204/Bodenkundliche _Kartieranleitung_5_Aufl (accessed November 26, 2018).

[87] G.S. Campbell, A simple method for determining unsaturated conductivity from moisture retention data, Soil Sci. 117 (1974) 311.

[88] S. Hauk, K. Skibbe, H. Röhle, J. Schröder, S. Wittkopf, T. Knoke, Nondestructive Estimation of Biomass Yield for Short-Rotation Woody Crops Is Reliable and Shows High Yields for Commercial Stands in Bavaria, BioEnergy Res. 8 (2015) 1401-1413. https://doi.org/10.1007/s12155-015-9602-5.

[89] T. Verwijst, B. Telenius, Biomass estimation procedures in short rotation forestry, For. Ecol. Manag. 121 (1999) 137-146. https://doi.org/10.1016/S0378-1127(98)00562-3.

[90] D.I. Dickmann, P.V. Nguyen, K.S. Pregitzer, Effects of irrigation and coppicing on above-ground growth, physiology, and fine-root dynamics of two field-grown hybrid poplar clones, For. Ecol. Manag. 80 (1996) 163-174. https://doi.org/10.1016/03781127(95)03611-3.

[91] P. Paris, L. Mareschi, M. Sabatti, A. Pisanelli, A. Ecosse, F. Nardin, G. ScarasciaMugnozza, Comparing hybrid Populus clones for SRF across northern Italy after two biennial rotations: Survival, growth and yield, Biomass Bioenergy. 35 (2011) 15241532. https://doi.org/10.1016/j.biombioe.2010.12.050.

[92] M.J. Aylott, E. Casella, I. Tubby, N.R. Street, P. Smith, G. Taylor, Yield and spatial supply of bioenergy poplar and willow short-rotation coppice in the UK, New Phytol. 178 (2008) 358-370. https://doi.org/10.1111/j.1469-8137.2008.02396.x.

[93] M.J. Tallis, E. Casella, P.A. Henshall, M.J. Aylott, T.J. Randle, J.I.L. Morison, G. Taylor, Development and evaluation of ForestGrowth-SRC a process-based model for short rotation coppice yield and spatial supply reveals poplar uses water more 
efficiently than willow, GCB Bioenergy. 5 (2013) 53-66.

https://doi.org/10.1111/j.1757-1707.2012.01191.x.

[94] U.B. Nielsen, P. Madsen, J.K. Hansen, T. Nord-Larsen, A.T. Nielsen, Production potential of 36 poplar clones grown at medium length rotation in Denmark, Biomass Bioenergy. 64 (2014) 99-109. https://doi.org/10.1016/j.biombioe.2014.03.030.

[95] M. Trnka, M. Trnka, J. Fialová, V. Koutecký, M. Fajman, Z. Žalud, S. Hejduk, Biomass production and survival rates of selected poplar clones grown under a shortrotation system on arable land, PLANT SOIL Env. (2008) 12.

[96] J. Smith, P. Smith, environmental modelling an introduction, 1. Auflage, Oxford University Press, Oxford, 2007.

[97] P. Smith, J.U. Smith, D.S. Powlson, W.B. McGill, J.R.M. Arah, O.G. Chertov, K. Coleman, U. Franko, S. Frolking, D.S. Jenkinson, L.S. Jensen, R.H. Kelly, H. KleinGunnewiek, A.S. Komarov, C. Li, J.A.E. Molina, T. Mueller, W.J. Parton, J.H.M. Thornley, A.P. Whitmore, A comparison of the performance of nine soil organic matter models using datasets from seven long-term experiments, Geoderma. 81 (1997) 153225. https://doi.org/10.1016/S0016-7061(97)00087-6.

[98] E. Pannacci, S. Bartolini, G. Covarelli, Evaluation of Four Poplar Clones in a Short Rotation Forestry in Central Italy, Ital. J. Agron. (2009) 191-198. https://doi.org/10.4081/ija.2009.4.191.

[99] L.S. Broeckx, M.S. Verlinden, G. Berhongaray, D. Zona, R. Fichot, R. Ceulemans, The effect of a dry spring on seasonal carbon allocation and vegetation dynamics in a poplar bioenergy plantation, GCB Bioenergy. 6 (2014) 473-487. https://doi.org/10.1111/gcbb.12087.

[100] S. Karrenberg, P.J. Edwards, J. Kollmann, The life history of Salicaceae living in the active zone of floodplains, Freshw. Biol. 47 (2002) 733-748. https://doi.org/10.1046/j.1365-2427.2002.00894.x.

[101] S. Karrenberg, J. Kollmann, P.J. Edwards, A.M. Gurnell, G.E. Petts, Patterns in woody vegetation along the active zone of a near-natural Alpine river, Basic Appl. Ecol. 4 (2003) 157-166. https://doi.org/10.1078/1439-1791-00123.

[102] S. Karrenberg, S. Blaser, J. Kollmann, T. Speck, P.J. Edwards, Root anchorage of saplings and cuttings of woody pioneer species in a riparian environment, Funct. Ecol. 17 (2003) 170-177. https://doi.org/10.1046/j.1365-2435.2003.00709.x.

[103] M. Weih, Intensive short rotation forestry in boreal climates: present and future perspectives, Can. J. For. Res. 34 (2004) 1369-1378. https://doi.org/10.1139/x04-090.

[104] A. Karp, S.J. Hanley, S.O. Trybush, W. Macalpine, M. Pei, I. Shield, Genetic Improvement of Willow for Bioenergy and BiofuelsFree Access, J. Integr. Plant Biol. 53 (2011) 151-165. https://doi.org/10.1111/j.1744-7909.2010.01015.x.

[105] S. Larsson, Genetic improvement of willow for short-rotation coppice, Biomass Bioenergy. 15 (1998) 23-26. https://doi.org/10.1016/S0961-9534(98)80003-2.

[106] K.K. Moritz, C. Björkman, A.L. Parachnowitsch, J.A. Stenberg, Plant sex effects on insect herbivores and biological control in a Short Rotation Coppice willow, Biol. Control. 115 (2017) 30-36. https://doi.org/10.1016/j.biocontrol.2017.09.006.

[107] W. Ali, Modelling of Biomass Production Potential of Poplar in Short Rotation Plantations on Agricultural Lands of Saxony, Germany, (2009).

http://tud.qucosa.de/landingpage/?tx_dlf[id]=http $\% 3 \mathrm{~A} \% 2 \mathrm{~F} \% 2 \mathrm{Ftud} . q u \operatorname{cosa} . d e \% 2 \mathrm{Fapi} \% 2 \mathrm{Fqucosa} \% 253 \mathrm{~A} 23743 \% 2 \mathrm{~F}$ mets (accessed March 8, 2019).

[108] R.J. Faasch, G. Patenaude, The economics of short rotation coppice in Germany, Biomass Bioenergy. 45 (2012) 27-40. https://doi.org/10.1016/j.biombioe.2012.04.012. 
[109] J. Schweier, G. Becker, Economics of poplar short rotation coppice plantations on marginal land in Germany, Biomass Bioenergy. 59 (2013) 494-502. https://doi.org/10.1016/j.biombioe.2013.10.020.

[110] A. Wael, Estimation of Production Potential of Short Rotation Forestry on Agricaltural Land of Saxony, in: Dtsch. Verband Forstl. Forschungsanstalten Jahrestag. 2007, Alsfeld-Eudorf, 2007.

[111] C. Pistocchi, W. Guidi, E. Piccioni, E. Bonari, Water requirements of poplar and willow vegetation filters grown in lysimeter under Mediterranean conditions: Results of the second rotation, Desalination. 246 (2009) 137-146. https://doi.org/10.1016/j.desal.2008.03.047.

[112] C. Herve, R. Ceulemans, Short-rotation coppiced vs non-coppiced poplar: A comparative study at two different field sites, Biomass Bioenergy. 11 (1996) 139-150. https://doi.org/10.1016/0961-9534(96)00028-1.

[113] C. Daly, M.D. Halbleib, D.B. Hannaway, L.M. Eaton, Environmental limitation mapping of potential biomass resources across the conterminous United States, GCB Bioenergy. 10 (2018) 717-734. https://doi.org/10.1111/gcbb.12496.

[114] T.A. Volk, B. Berguson, C. Daly, M.D. Halbleib, R. Miller, T.G. Rials, L.P. Abrahamson, D. Buchman, M. Buford, M.W. Cunningham, M. Eisenbies, E.S. Fabio, K. Hallen, J. Heavey, G.A. Johnson, Y.A. Kuzovkina, B. Liu, B. Mcmahon, R. Rousseau, S. Shi, R. Shuren, L.B. Smart, G. Stanosz, B. Stanton, B. Stokes, J. Wright, Poplar and shrub willow energy crops in the United States: field trial results from the multiyear regional feedstock partnership and yield potential maps based on the PRISMELM model, GCB Bioenergy. 10 (2018) 735-751. https://doi.org/10.1111/gcbb.12498.

[115] M.-L. Linderson, Z. Iritz, A. Lindroth, The effect of water availability on stand-level productivity, transpiration, water use efficiency and radiation use efficiency of fieldgrown willow clones, Biomass Bioenergy. 31 (2007) 460-468. https://doi.org/10.1016/j.biombioe.2007.01.014. 